OPEN ACCESS

Edited by:

Giuseppe Sconocchia,

Consiglio Nazionale Delle

Ricerche (CNR), Italy

Reviewed by:

Muller Fabbri,

Children's Hospital of

Los Angeles, United States

Julian Pardo,

Fundación Agencia Aragonesa

para la Investigación

y el Desarrollo (ARAID), Spain

*Correspondence:

Girdhari Lal

glal@nccs.res.in

Specialty section:

This article was submitted to Cancer Immunity and Immunotherapy,

a section of the journal

Frontiers in Immunology

Received: 27 June 2017

Accepted: 28 August 2017

Published: 13 September 2017

Citation:

Paul S and Lal G (2017) The

Molecular Mechanism of

Natural Killer Cells Function

and Its Importance in Cancer Immunotherapy.

Front. Immunol. 8:1124. doi: 10.3389/fimmu.2017.01124

\section{The Molecular Mechanism of Natural Killer Cells Function and Its Importance in Cancer Immunotherapy}

\author{
Sourav Paul and Girdhari Lal* \\ National Centre for Cell Science, Pune, India
}

Natural killer (NK) cells are innate immune cells that show strong cytolytic function against physiologically stressed cells such as tumor cells and virus-infected cells. NK cells show a broad array of tissue distribution and phenotypic variability. NK cells express several activating and inhibitory receptors that recognize the altered expression of proteins on target cells and control the cytolytic function. NK cells have been used in several clinical trials to control tumor growth. However, the results are encouraging only in hematological malignancies but not very promising in solid tumors. Increasing evidence suggests that tumor microenvironment regulate the phenotype and function of NK cells. In this review, we discussed the NK cell phenotypes and its effector function and impact of the tumor microenvironment on effector and cytolytic function of NK cells. We also summarized various NK cell-based immunotherapeutic strategies used in the past and the possibilities to improve the function of NK cell for the better clinical outcome.

Keywords: natural killer cells, tumor microenvironment, inflammation, innate immune cells, cancer immunotherapy

\section{INTRODUCTION}

Natural killer (NK) cells are a group of innate immune cells that show spontaneous cytolytic activity against cells under stress such as tumor cells and virus-infected cells. After activation, NK cells also secrete several cytokines such as interferon- $\gamma$ (IFN- $\gamma$ ), tumor necrosis factor- $\alpha$ (TNF- $\alpha$ ), granulocyte macrophage colony-stimulating factor (GM-CSF), and chemokines (CCL1, CCL2, CCL3, CCL4, CCL5, and CXCL8) that can modulate the function of other innate and adaptive immune cells. $\mathrm{NK}$ cells are identified as $\mathrm{CD}^{-} \mathrm{NK} 1.1^{+}$cells in $\mathrm{C} 57 \mathrm{BL} / 6, \mathrm{FVB} / \mathrm{N}$, and NZB strains of mice. BALB/c, CBA/J, AKR, C3H, DBA/1, DBA/2, NOD, SJL, and 129 strains of mice do not express NK1.1 and NK cells in these mice can be identified as $\mathrm{CD}^{-} \mathrm{CD} 49 \mathrm{~b}^{+}$cells. NK cells in human are identified as

Abbreviations: ADCC, antibody-dependent cell-mediated cytotoxicity; AML, acute myeloid leukemia; CAR, chimeric antigen receptor; CB, cord blood; CLP, common lymphoid progenitor; DNAM-1, DNAX accessory molecule-1; ERK, extracellular signal-regulated kinase; FasL, Fas ligand; GM-CSF, granulocyte macrophage colony-stimulating factor; HCT, hematopoietic cell transplantation; IFN- $\gamma$, interferon- $\gamma$; ITAM, immunoreceptor tyrosine-based activation motif; ITIM, immunoreceptor tyrosine-based inhibitory motif; MCA, methylcholanthrene; MCMV, murine cytomegalovirus; MDSCs, myeloid-derived suppressor cells; NCRs, natural cytotoxicity receptors; NK, natural killer; NKG2A, natural-killer group 2, member A; NKG2D, natural-killer group 2, member D; KIR, killer cell immunoglobulin-like receptor; TGF- $\beta$, transforming growth factor- $\beta$; PB, peripheral blood; Rae-1, retinoic acid early inducible-1; SHIP-1, Src homology 2-containing inositol 5'-polyphosphatase-1, SHP, Src homology domain-containing tyrosine phosphatase; TNF- $\alpha$, tumor necrosis factor- $\alpha$; TRAIL, TNF-related apoptosisinducing ligand; Tregs, regulatory $\mathrm{T}$ cells. 
$\mathrm{CD}^{-}{ }^{-} \mathrm{CD} 56^{+}$cells. They represent $2-7 \%$ of lymphocytes in mouse peripheral blood (PB) and 5-15\% of human peripheral blood mononuclear cells (PBMCs). NK cells are present in the skin, gut, liver, lung, uterus, kidney, joints, and breast under physiological conditions. NK cells constitute about $20-30 \%$ of total hepatic lymphocytes and $10 \%$ of lymphocytes in healthy human liver and lung, respectively (1). The specific subset of NK cell is reported to control the development at the fetal-maternal interface during the first trimester of the pregnancy, and it constitutes about $50-90 \%$ of total lymphoid cells in the uterus $(2,3)$. These uterine NK cells secrete IL-8, vascular endothelial growth factor (VEGF), stromal cell-derived factor-1, and interferon gamma-inducible protein-10 (IP-10) which help in tissue building, remodeling, and angiogenesis (4). NK cells in human placenta do not show killer activity but assist in establishing immunosuppression and tolerance to fetus allograft. Similar to T and B cells, NK cells also develop from common lymphoid progenitor cells (5). Although bone marrow is the primary site of NK cell development (6), they can also develop in the liver and thymus (7). The development of NK cells progresses through various stages of maturation, expansion, and acquisition of specific receptors. All NK receptors are germ-line encoded and independent of RAG-mediated recombination (8). Multiple factors such as cell-intrinsic signals (transcription factors) and external signals (cytokines and growth factors) govern the development of NK cells. NK cells constitute the major component of an innate immune system and play the crucial role in shaping the early immune response to viral infection and tumors and also in organ transplantation (9). In this review, we discussed what are inhibitory and activating molecules present on NK cells and how they control NK cell function, how do NK cell function in the tumor microenvironment, use of NK cell as adoptive cellular therapy to control cancer and what are strategies to improve NK cell antitumor function.

\section{EFFECTOR AND REGULATORY PHENOTYPE OF NK CELLS}

Natural killer cell stimulation and effector function depend upon the integration of signals derived from two distinct types of receptors-activating and inhibitory receptors (Table 1). Normal healthy cells express MHC class I molecules on their surface which act as ligands for inhibitory receptors and contribute to the self-tolerance of NK cells. However, virus-infected cells or tumor cells lose surface MHC class I expression, leading to lower inhibitory signal in NK cells. Simultaneously, cellular stress associated with viral infection or tumor development such as DNA damage response, senescence program or tumor suppressor genes upregulate ligands for activating receptors in these cells. As a result, the signal from activating receptors in NK cell shifts the balance toward NK cell activation and elimination of target cells directly through NK cell-mediated cytotoxicity or indirectly through secretion of pro-inflammatory cytokines (10) (Figure 1).

\section{Inhibitory Receptors on NK Cells}

Inhibitory receptors signal through immunoreceptor tyrosinebased inhibitory motifs (ITIM) present in their cytoplasmic tails.
TABLE 1 | Activating and inhibitory receptors on NK cells.

\begin{tabular}{|c|c|c|c|}
\hline Type & Receptors & Ligands & Species \\
\hline \multirow[t]{18}{*}{$\begin{array}{l}\text { Activating } \\
\text { receptors }\end{array}$} & NKG2D & $\begin{array}{l}\text { Mouse: Rae1a-e, MULT-1, H60 } \\
\text { Human: MIC-A-B, ULBP1-4 }\end{array}$ & $\begin{array}{l}\text { Mouse/ } \\
\text { human }\end{array}$ \\
\hline & CD94-NKG2C & $\begin{array}{l}\text { Mouse: Qa1b } \\
\text { Human: HLA-E }\end{array}$ & $\begin{array}{l}\text { Mouse/ } \\
\text { human }\end{array}$ \\
\hline & Ly49D & Mouse: $H-2 D^{d}$ & Mouse \\
\hline & Ly49H & Mouse: m157 of MCMV & Mouse \\
\hline & KIR2DL4 & Human: HLA-G & Human \\
\hline & KIR2DS1 & Human: HLA-C2 & Human \\
\hline & KIR2DS2 & Human: HLA-C1 & Human \\
\hline & KIR2DS3 & Unknown & Human \\
\hline & KIR2DS4 & Human: HLA-A11 & Human \\
\hline & KIR2DS5 & Unknown & Human \\
\hline & KIR3DS1 & Human: HLA-Bw4 & Human \\
\hline & NKp30 & $\begin{array}{l}\text { Human: B7H6, BAT3, pp65 of HCMV, } \\
\text { PfEMP1 of Plasmodium falciparum, } \\
\text { viral HA }\end{array}$ & Human \\
\hline & NKp46 & Heparin, viral HA and HN & $\begin{array}{l}\text { Mouse/ } \\
\text { human }\end{array}$ \\
\hline & NKp44 & Viral $\mathrm{HA}$ and $\mathrm{HN}, \mathrm{PCNA}$, proteoglycans & Human \\
\hline & NKR-P1C & & Mouse \\
\hline & NKR-P1F & Mouse: Clr-g, Clr-c & Mouse \\
\hline & NKR-P1G & Mouse: Clr-g, Clr-f & Mouse \\
\hline & DNAM-1 & Mouse and human: CD112, CD155 & $\begin{array}{l}\text { Mouse/ } \\
\text { human }\end{array}$ \\
\hline \multirow{15}{*}{$\begin{array}{l}\text { Inhibitory } \\
\text { receptors }\end{array}$} & Ly49A & Mouse: $\mathrm{H}-2 \mathrm{D}^{\mathrm{b}, \mathrm{d}, \mathrm{k}, \mathrm{p}}, \mathrm{H}-2 \mathrm{M} 3$ & Mouse \\
\hline & Ly49C & Mouse: $\mathrm{H}-2 \mathrm{D}^{\mathrm{b}, \mathrm{d}, \mathrm{k}} \mathrm{H}-2 \mathrm{~K}^{\mathrm{b}, \mathrm{d}, \mathrm{k}} \mathrm{m} 157$ & Mouse \\
\hline & Ly49| & Mouse: $\mathrm{H}-2 \mathrm{k}^{\mathrm{b}, \mathrm{s}, \mathrm{q}, \mathrm{v}}$ & Mouse \\
\hline & Ly49P & Mouse: $\mathrm{H}-2 \mathrm{D}^{\mathrm{d}, \mathrm{k}}$ & Mouse \\
\hline & KIR2DL1 & Human: HLA-C2 & Human \\
\hline & KIR2DL2 & Human: HLA-C1 & Human \\
\hline & KIR2DL3 & Human: HLA-C1 & Human \\
\hline & KIR3DL1 & Human: HLA-Bw4 & Human \\
\hline & KIR3DL2 & Human: HLA-A3,-A11 & Human \\
\hline & NKR-P1A & Human: LLTI & Human \\
\hline & NKR-P1B & Mouse: Clr-b & Mouse \\
\hline & NKR-P1D & & \\
\hline & CD94-NKG2A & $\begin{array}{l}\text { Mouse: Qa1b } \\
\text { Human: HLA-E }\end{array}$ & $\begin{array}{l}\text { Mouse/ } \\
\text { human }\end{array}$ \\
\hline & ILT2 (CD85j) & $\begin{array}{l}\text { Human: HLA-A, -B, -C, HLA-G1, } \\
\text { HCMV UL18 }\end{array}$ & Human \\
\hline & CD244(2B4) & Mouse and human: CD48 & $\begin{array}{l}\text { Mouse/ } \\
\text { human }\end{array}$ \\
\hline
\end{tabular}

Upon ligand engagement, ITIMs undergo phosphorylation and recruit phosphatases such as Src homology-containing tyrosine phosphatase 1 (SHP-1), SHP-2, and lipid phosphatase SH2 domain-containing inositol-5-phosphatase (SHIP) which further neutralize the activating signals (11). During NK cell inhibitory signaling, the phosphatases SHP-1 and SHP-2 dephosphorylate the immunoreceptor tyrosine-based activation motif (ITAM)bearing Vav-1 molecules and prevent the downstream signaling $(12,13)$ (Figure 2).

Ly49 receptors represent one of the major families of mouse NK cell inhibitory receptors. Ly49 receptors are type II glycoprotein of C-type lectin-like superfamily and composed of carboxyterminal lectin domain also known as NK domain (NKD) (14). Ly49 receptors bind to MHC class I molecules through their $\mathrm{NKD}$, and this interaction is MHC-peptide independent. The Ly 49 family of proteins are highly polymorphic which results in 


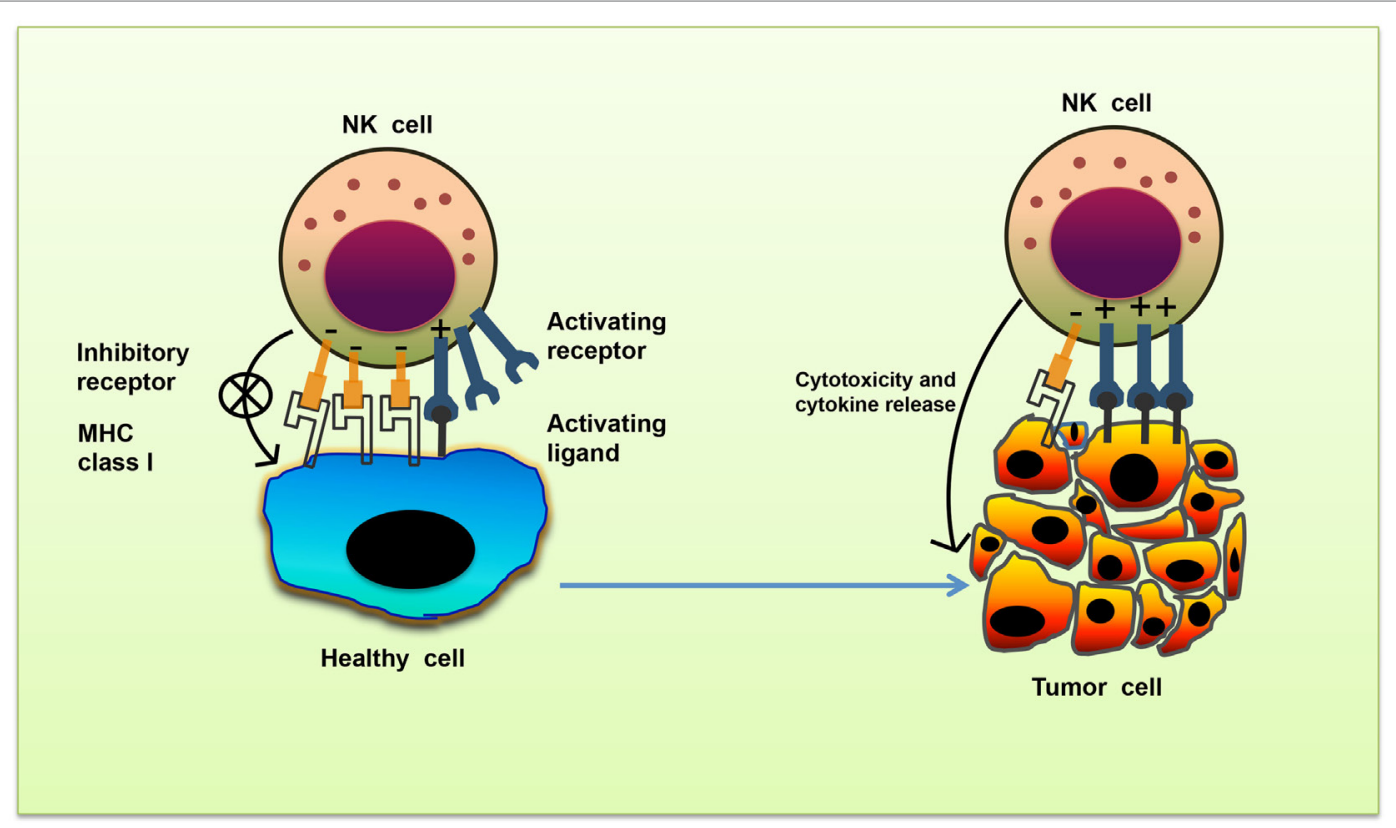

FIGURE 1 | Missing-self recognition of target cells. The activating and inhibitory receptor signaling regulates the natural killer (NK) cells activation. Cells undergoing stress such as tumor cells lose their MHC class I molecules, a ligand for inhibitory receptors on NK cells. At the same time, they acquire stress-associated molecules which act as ligands for activating receptors. Thus, the lack of inhibitory signaling coupled with induction of activating signaling shifts the balance toward NK cell activation, leading to secretion of cytokines and killing of tumor cells.

heterogeneous expression among different inbred mouse strains. The Ly49 receptor family includes Ly49A, Ly49C, Ly49I, and Ly49P molecules. The prototype member Ly49A binds to $\mathrm{H}-2 \mathrm{D}^{\mathrm{d}}, \mathrm{H}-2 \mathrm{D}^{\mathrm{k}}$, and the non-classical MHC-I molecule H2-M3 while Ly49C binds to $\mathrm{H}-2 \mathrm{~K}^{\mathrm{b}}$ and $\mathrm{H}-2 \mathrm{D}^{\mathrm{b}}$ molecules (15). Human express functionally equivalent homolog of Ly49 member which are known as killer cell immunoglobulin-like receptor (KIR) family of proteins (16). KIRs are type I transmembrane protein with two or three IgG-like domains and a short or long cytoplasmic tail. KIRs bind to HLAA, $-\mathrm{B}$, and $-\mathrm{C}$ molecules. In contrast to Ly49 family, KIRs bind to the peptide-binding region of HLA molecules. The heterogeneity of KIR repertoire expression among different individuals is due to the difference in the expression of KIR molecules on individual NK cells as well as allelic variation in KIR genes. Inhibitory KIRs include KIR2DL1-3, KIR2DL5, and KIR3DL1-3 (17). Both KIRs and inhibitory Ly49 receptors contribute to NK cell tolerance to self-tissues (18). CD94-natural-killer group 2, member A (NKG2A) is another C-type lectin family of the inhibitory receptor that expresses as a heterodimer and contain ITIM. This receptor specifically recognizes non-classical MHC molecules on target cells and protect host cell against inappropriate NK cell activation $(19,20)$. Human NKG2A recognizes non-classical MHC molecule HLA-E $(21,22)$ while mouse counterpart interacts with the Qa1 molecule (23). There are several cytokines present in the tissue microenvironment that can modulate the expression of NKG2A and affect NK cell function.

\section{Activating Receptors on NK Cells}

Lack of MHC class I on the target cell is not sufficient to trigger NK cell activation. Full NK cell activation also requires recognition of stress-induced molecules by NK cell activating receptors. The effector function of NK cell utilizes integrated signaling from an array of activating receptors on NK cells (Table 1). Most activating receptors signal through ITAMs defined by the sequence D/EXXYXX(L/I)X $\mathrm{X}_{6-8} \mathrm{YXXL} / \mathrm{I}$ (where $\mathrm{X}_{6-8}$ is 6-8 amino acids stretch between two XXL/I element). Engagement of receptor-ligand complexes leads to phosphorylation of ITAM by Src family of tyrosine kinases such as Lck, Fyn, Src, Yes, Fgr, and Lyn. Phosphorylation of ITAM subunit leads to recruitment and activation of the tyrosine kinase Syk and Zap70. The downstream signaling pathway of Zap70 phosphorylation involves phosphorylation of different proteins such as SLP-76, Shc, and phosphatidylinositol-3-OH kinase [PI(3)K], assembly of Grb2, linker for the activation of T cells (LAT), Vav-1, and Vav-2, activation of mitogen-activated protein kinases (MAPKs) and extracellular signal-regulated kinases (ERKs). The outcome of these signals result in the elevation of calcium levels and reorganization of actin cytoskeleton leading to release of cytolytic granules containing perforin and granzymes and transcription of cytokine and chemokine genes (24) (Figure 3).

The activating receptor natural-killer group 2, member $\mathrm{D}$ (NKG2D) is a C-type lectin-like type II transmembrane protein expressed as a homodimer on the surface of all murine and human NK cells. It is also expressed by most NKT cells and activated $\mathrm{CD}^{+} \mathrm{T}$ cells in mice, and all CD $8^{+} \mathrm{T}$ cells and a subset of $\gamma \delta \mathrm{T}$ cells in humans (25). The NKG2D receptor is a hexameric complex composed of single NKG2D homodimer along with two DAP10 homodimers (26). In mice, NKG2D is present in two different isoforms, short isoform (NKG2D-S) and a long isoform (NKG2D-L), which are generated by alternative splicing (27). NKG2D-S can 


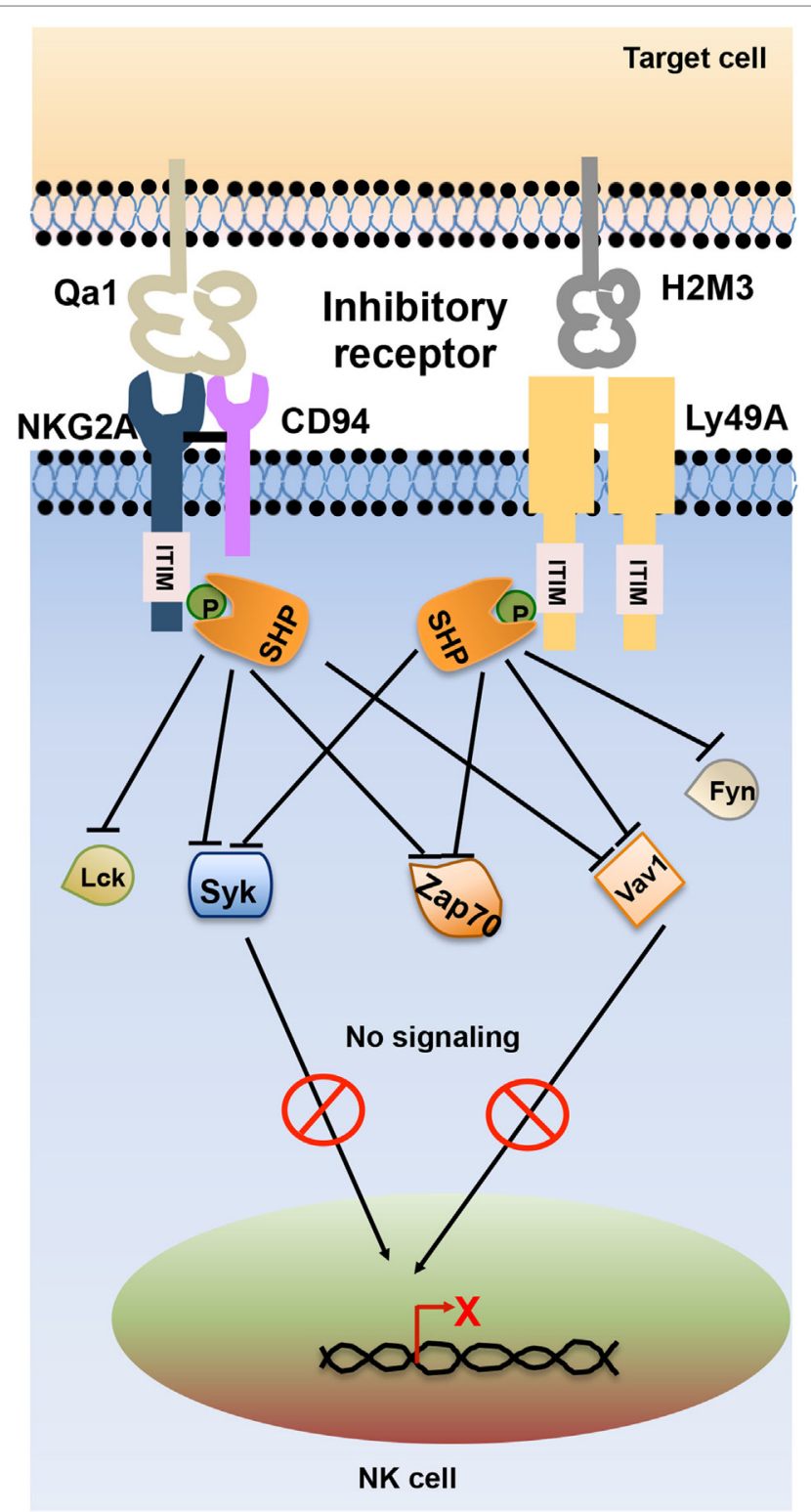

FIGURE 2 | Schematic representation of natural killer (NK) cell inhibitory receptor signaling. The interaction of NK cell inhibitory receptors natural-killer group 2, member A (NKG2A) and Ly49A with its cognate ligand leads to phosphorylation of immunoreceptor tyrosine-based inhibitory motif (ITIM) in their cytoplasmic tails. Phosphorylated ITIM recruits phosphatases such as Src homology domain-containing tyrosine phosphatase (SHP) and $\mathrm{SH} 2$ domain-containing inositol-5-phosphatase (SHIP) that dephosphorylate signaling molecules such as Lck, Fyn, Syk, Zap70, and Vav1, thereby terminating activating receptor signaling in NK cells.

associate with both DAP10 and DAP12 while NKG2D-L only pair with DAP10. NKG2D-S is not present in human and NKG2D-L can only associate with DAP10 in human (27). DAP10 cytoplasmic domain contains YINM motif which is phosphorylated by Src family of kinases or Jak3 kinase and recruits p85 subunit of PI3K or Grb2 adaptor protein. Grb2 phosphorylation induces phosphorylation of Vav1, PLC- $\gamma 2$, and SLP-76. PI3K and Grb-Vav1

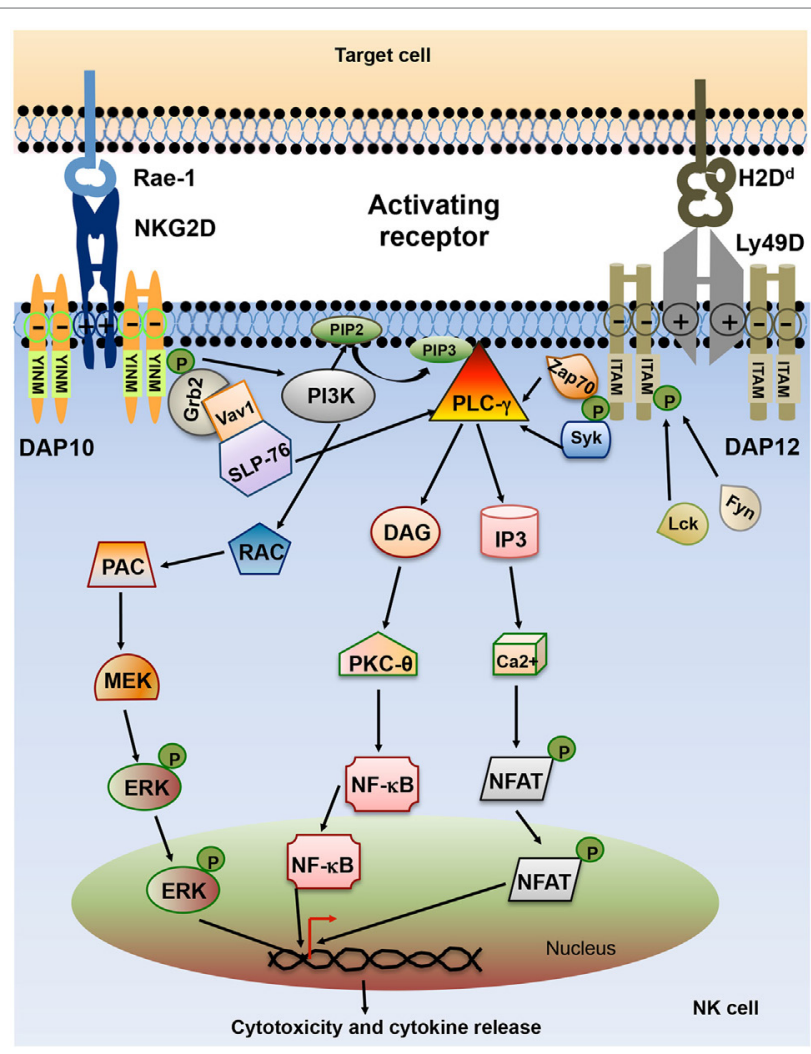

FIGURE 3 | Schematic representation of natural killer (NK) cell activating receptor signaling. Interaction of activating receptor NKG2D and Ly49D with their cognate ligand leads to phosphorylation of YINM motif or immunoreceptor tyrosine-based activation motifs (ITAMs) present in the cytoplasmic tails of associated adapter protein such as DAP10 and DAP12. Phosphorylated ITAM or YINM motif recruits Syk/Zap70, PI3K, and Grb2/ Vav1/SLP-76 complex. Grb2Nav1/SLP-76 pathway activation leads to downstream activation of MEK/extracellular signal-regulated kinase (ERK) pathway. Phosphorylated Syk recruits PLC- $\gamma$ which in turn activates inducible protein-3 (IP-3) and DAG pathway leading to activation of transcription factors NF- $\mathrm{KB}$ and NFAT. The net result of this signaling is the release of cytokines and chemokines as well as cytotoxic molecules by the NK cells (24).

signaling induce phosphorylation of Jak2, STAT5, Akt, MEK1/2, and Erk (28-31). Effector function of DAP10 signaling in NK cell is distinct from DAP12 signaling. Deficiency of DAP10 and DAP12 in mice and human NK cells has shown that NKG2D-DAP12 signaling can induce both cytotoxicity and cytokine secretion whereas signaling through DAP10 mostly activates cytotoxicity $(27,32,33)$. The cytokines such as IL-7, IL-12, and IL-15 upregulate the expression of NKG2D on NK and CD8 ${ }^{+}$T cells, whereas IFN- $\gamma$ and transforming growth factor- $\beta$ (TGF- $\beta$ ) reduce it (34-36). The NKG2D molecule in human and mice binds several ligands which are highly polymorphic and are structural homologs of MHC class I molecules. The ligands of murine NKG2D are retinoic acid early inducible- 1 family of proteins (Rae-1 $\alpha-\varepsilon)$, murine UL16-binding protein-like transcript 1 (MULT1) and H60 group of proteins (H60a, H60b, H60c) (37-39). There are two families of NKG2D ligands in human, MHC class I chain-related protein $\mathrm{A}$ (MICA) and B (MICB) and UL16-binding proteins (ULBP1-6) 
(40). NKG2D ligands are expressed at low levels in healthy adult cells in both mice and human $(40,41)$. However, these ligands are upregulated and widely expressed in tumors of diverse tissue origin. Mouse NKG2D ligands have been detected in lymphoma cells, lung, colon, rectal and prostate cancer cell lines (41-43). However, lymphoma cell lines RMA and RMA-S, and melanoma cell line B16F10 lack expression of NKG2D ligands (37). A wide range of tumors such as leukemia, glioma, neuroblastoma (NB), melanoma, breast, lung, colon, kidney, and prostate tumors are known to express human MIC and ULBP (44-48). The level of expression of NKG2D ligands varies significantly between tumor types and stages of tumor progression. Ataxia telangiectasia mutated kinase and Rad3-related kinase (ATR), DNA damage repair pathway, cytokines, and TLR signaling are known to regulate the expression of NKG2D ligands (49-51). Pharmacological drugs such as proteasome inhibitors and histone deacetylase inhibitors also control NKG2D ligand expression $(52,53)$. In addition to NKG2D, two other members of NKG2 family, NKG2C and NKG2E act as an activating receptor and are known to express as a heterodimer with the CD94 molecule $(19,54)$. CD94-NKG2C and CD94-NKG2E heterodimer recognize class Ib molecule Qa- $1^{\mathrm{b}}$ and interact with DAP12 and activate downstream signaling $(55,56)$.

Although the majority of Ly49 receptors are inhibitory in nature, some Ly49 receptors such as Ly49D and Ly49H show activation function in C57BL/6 mice. Ly49D and Ly49H associated with the DAP12 molecule and transduce the signal through ITAM (57). Activation of the Ly49 receptor leads to phosphorylation of ITAM and recruitment of Syk tyrosine kinase (58). Ly49 receptors on NK cells play a critical role in host defense against viral infection. Ly $49 \mathrm{H}$ binds to the glycoprotein m157 protein of murine cytomegalovirus (MCMV) and imparts resistance to MCMV infection (59). Other Ly49 activating receptors such as Ly49D, Ly49P, and Ly49W are reported to bind $\mathrm{H}-2 \mathrm{D}^{\mathrm{d}}$ molecules (60-62). The activating KIR utilizes DAP12 adapter molecule for downstream signaling. The generation of activating Ly49 and KIR molecules was thought to be a result of convergent evolution from their respective ancestral inhibitory receptors (63).

Natural cytotoxicity receptors (NCRs) are another immunoglobulin superfamily of activating receptors that utilize extracellular immunoglobulin-like domain for ligand binding. Human NK cells express three distinct types of NCRs such as NKp46 (NCR1 or CD335), NKp44 (NCR2 or CD336), and NKp30 (NCR3 or CD337) while mouse NK cells express only NKp46 (64-66). NKp46 and NKp30 are expressed on both resting and activated NK cells, whereas NKp44 expression is restricted to activated NK cells. NCRs can bind to adaptor proteins FceRI- $\gamma$ and CD3- $\zeta$ which then transduce the signal through ITAM (67). NCRs recognize a wide variety of ligands on target cells ranging from viral, bacterial and parasite proteins to molecules from tumor cells and other host cells (67).

The 2B4 receptor (CD244) present in mouse and human NK cells belong to signaling lymphocyte activation molecule family of membrane receptors and depending on the adapter protein recruited at the cytoplasmic tail they can act as activating as well as an inhibitory receptor. CD244 predominantly acts as an inhibitory receptor in mice. NK cells from CD244 deficient mice were shown to have enhanced cytotoxicity and cytokine secretion and also help in efficiently rejecting the B16F10 melanoma $(68,69)$. However, neutralizing antibodies to human CD244 blocks the killing of CD48-expressing target cells. It has been shown that mouse cell lines transfected with human CD48 can be efficiently targeted and killed by human NK cells. These studies suggest that CD244 acts as an activating receptor in human NK cells $(70,71)$. The activating or inhibitory function of CD244 in human and mice may be influenced by other inhibitory and activating receptor signals and can also be perturbed by the relative expression of SAP, EAT-2, and ERT molecules involved in the downstream signaling.

CD38 is an enzyme that catalyzes the conversion of betaNecotinamide adenine dinucleotide (beta-NAD ${ }^{+}$) and betanecotinamide adenine dinucleotide 2'-phosphate (beta-NADP ${ }^{+}$) into cyclic adenosine diphosphate-ribose (ADPR) and nicotinic acid adenine dinucleotide phosphate (NAADP). CD38 has been shown to trigger the cytotoxic activity of NK cells against tumor cells by promoting the granule polarization and degranulation in NK cells. The ADPR produced by CD38 gets localized to cytolytic granules in response to stimulation and modulates $\mathrm{Ca}^{++}$signaling, thereby causing degranulation in NK cells (72). Another study by Mallone et al. showed that CD38 engagement by agonistic monoclonal antibody (mAb) induces phosphorylation of CD3- $\zeta$, FceRI and ZAP-70 proteins leading to release of IFN- $\gamma$ and GM-CSF and lysis of target cells (73). CD44 is also constitutively expressed by resting NK cells. However, stimulation of NK cells with IL-2 or IL-15 leads to upregulation and activation of CD44. The low molecular weight hyaluronic acid in combination with IL-2, IL-12, or IL-18 could trigger activated CD44 and promote IFN- $\gamma$ production in NK cells (74). Crosslinking of CD44 with the mAb on NK cells also induces TNF- $\alpha$ production and CD16-mediated NK cell cytotoxicity (75).

The triggering of cytokines and chemokines secretion by NK cell and NK cell-mediated cytotoxicity requires a synergistic combination of several receptors. Using cross-linking antibodies to NK receptors, it has been shown that only CD16 alone could trigger degranulation of resting human NK cells while most activating receptors such as NKG2D and NCRs could perform activation only in combination with other receptors $(76,77)$. This synergistic activation of several receptors leads to convergence of signals toward a central signaling molecule so that its level reaches the threshold required for activation of NK cells.

\section{Costimulatory Receptors on NK Cells}

Costimulatory receptors synergize with other activating receptors to provide additional stimulation. NKR-P1 in mouse acts as activating as well as an inhibitory costimulatory receptor. NKR$\mathrm{P} 1$ is a member of type II glycoprotein receptors of C-type lectin superfamily and consist of five members: NKR-P1A, -B, -C, -D, and -E. NKR-P1C is mostly known to be associated with NK1.1 molecules and provides activating signal whereas NKR-P1B and -D contain ITIM and display inhibitory function $(78,79)$. Another costimulatory activating receptor is DNAX accessory molecule-1 (DNAM-1) or CD226, a member of Ig superfamily. DNAM-1 recognizes CD155 (also known as Poliovirus receptor or PVR) and CD112 (Nectin-2) on tumor cells and induces NK cell-mediated lysis (80). DNAM-1 has been shown to bind lymphocyte function-associated antigen 1 and promote adhesion 
of monocytes suggesting that DNAM-1 also plays a significant role in NK cell migration (81).

\section{CYTOTOXIC AND EFFECTOR IMMUNE RESPONSE OF NK CELLS}

\section{Cytotoxic Immune Response of NK Cells}

The NK cell cytotoxic response is divided into four major steps. (1) Formation of immunological synapse between the target cell and NK cell, followed by reorganization of actin cytoskeleton. (2) Polarization of microtubule organizing center (MTOC) and secretory lysosome toward lytic synapse. (3) Docking of secretory lysosome with the plasma membrane of NK cells. (4) Fusion of secretory lysosome with the plasma membrane of target cells. This entire process leading to the release of cytotoxic molecules such as perforin and granzyme is known as degranulation. This degranulation of NK cells is often used for indirect measurement of NK cell cytotoxic activity (82) (Figure 4). During the NK cell degranulation, lysosomal-associated membrane protein-1 (LAMP-1 or CD107a) and -2 (LAMP-2 or CD107b) transiently appears on the surface of NK cells. The expression of LAMP-1 on NK cell surface has been used as an indirect measurement of NK cells cytolytic function (83). Perforin released in the target cells polymerizes and forms the pores, and facilitating the entry of granzymes into the target cell. Granzymes are serine proteases which activate caspase molecules leading to induction of apoptosis of target cells $(24,82,84)$. Perforin-dependent cytotoxicity is crucial for NK cell-mediated control of several tumors $(85,86)$.
Another process by which NK cell mediates killing of target cells involves death receptor-induced target cell apoptosis. NK cells express TNF receptor ligand-Fas ligand (FasL), TNF, and TRAIL which binds to their corresponding receptor on target cells (87). Engagement of death receptor with its cognate ligand induces a conformational change in the receptor and recruitment of adaptor protein leading to apoptosis of target cells $(88,89)$. NK cellmediated control of methylcholanthrene (MCA) metastasis has been shown to be TRAIL dependent (90). Fas-FasL pathway contributes to the antimetastatic potential of IL-18-treated NK cells (91). These studies suggest that NK cells use various molecules to induce the cytotoxic function against physiologically stressed cells.

It has been shown that exosomes produced by immune cells can promote the antitumor immunity whereas tumor cellderived exosomes in tumor microenvironment can inhibit the effector immune response (92). Recent studies have shown that both resting and activated human NK cells secrete exosomes that have NK cell-specific marker CD56 and several other NK cellassociated molecules such as NKp30, NKp44, NKG2D, and NKp46. These exosomes also have FasL and perforin molecules and exert cytotoxic activity against various human tumor cell lines (93). Another study reported that exosomes produced by NK cells that have been pre-exposed to NB cells (Nx-ANKs) show higher expression of different activating receptors such as NKp30, NKp44, NKp46, and NKG2D and also have enhanced cytotoxicity when compared with untreated NK cells (92). These findings suggest that NK cells pre-exposed to NB cell-derived exosomes have undergone education which results in efficient cytotoxicity against NB tumors (92).

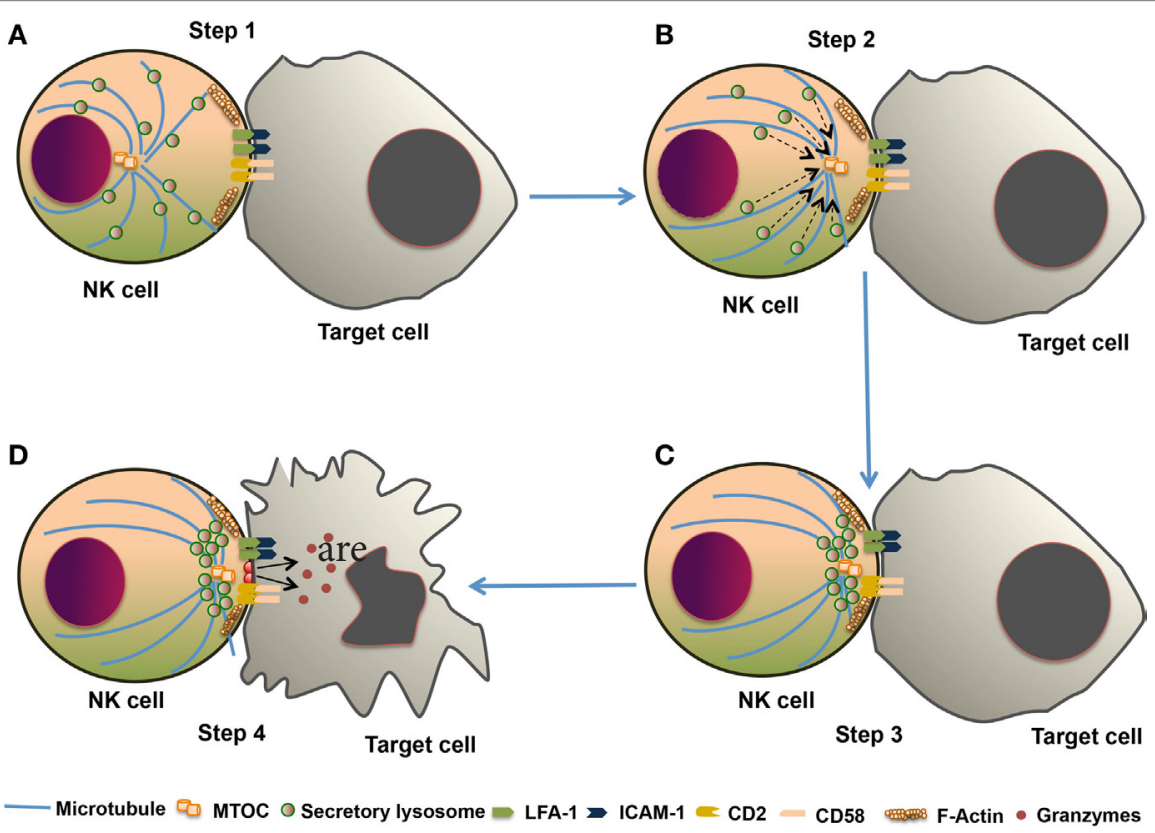

FIGURE 4 | The cytotoxic response of natural killer (NK) cells. The NK cell cytotoxic response is tightly regulated in four discrete stages. (A) Step 1: Recognition of target cells by NK cell results in the reorganization of actin cytoskeleton and the formation of immunological synapse, and clustering of cell adhesion molecules such as lymphocyte function-associated antigen 1 (LFA-1) and CD2. (B) Step 2: microtubule organizing center (MTOC) and secretory lysosome polarize toward the immunological synapse. (C) Step 3: docking which involves moves close to the plasma membrane of NK cell at the synapse. (D) Step 4: secretory lysosome fuse with the target cell plasma membrane and releases the cytotoxic granules into the target cell. 


\section{Effector Immune Response of NK Cells}

Activated NK cells secrete a wide variety of cytokines such as IFN- $\gamma$, TNF- $\alpha$, GM-CSF, IL-10, IL-5, and IL-13 and chemokines such as MIP- $1 \alpha$, MIP- $1 \beta$, IL-8, and RANTES (94-96). IFN- $\gamma$ is one of the most potent effector cytokines secreted by NK cells and plays a crucial role in antiviral, antibacterial, and antitumor activity. IFN- $\gamma$ has been shown to modulate caspase, FasL, and TRAIL expression and activates antitumor immunity (97). The tumor stromal cells control the secretion of effector cytokines in NK cells. Signaling through activating receptor NKG2D on NK cell has been shown to promote the release of IFN- $\gamma$ (98). IL-12 produced by dendritic cells, macrophages, and neutrophils can also induce the production of IFN $-\gamma$ in NK cells, which could be further enhanced by TNF- $\alpha$, IL-1, and IL-18 $(99,100)$. In contrast, TGF- $\beta$ inhibits the production of IFN- $\gamma$, TNF- $\alpha$, and GM-CSF in NK cells (101). IL-10 is also a potent inducer of $\mathrm{NK}$ cell proliferation, cytotoxic function, and IFN- $\gamma$ production in combination with IL-18 (102). Treatment with IL-18 promotes regression of melanoma tumor in the NK cell-dependent manner (103). IL-12 treatment inhibits tumor metastasis in the NKG2D and perforin-dependent manner, while the antimetastatic effect of IL-18 in the same setting is FasL dependent (43). IL-21 has also been known to induce NK cell activation in vivo in melanoma and renal cell carcinoma patients and also mediate rejection of various murine tumors in a NKG2D-dependent manner (104, 105). IL-15 is known to activate NK cell function and suppress tumor growth. These studies point out that apart from the NK cell cytotoxic function, cytokines secreted by the NK cells also provide a significant boost to the antitumor immunity. Similarly, the cytokines secreted by other immune cells or stromal cells in the tumor microenvironment can positively or negatively influence the antitumor function of NK cells.

\section{TOLEROGENIC AND INFLAMMATORY FUNCTION OF NK CELLS}

\section{NK Cell Tolerance and Education}

Natural killer cell tolerance to self-molecules is dependent on recognition of MHC class I molecules on target cells by inhibitory receptors present on NK cells. Many of the activating receptors expressed by mouse and human NK cells recognize self-ligands, thus raising the possibility of autoreactivity unless restrained by inhibitory receptors. When NK cells develop in the presence of self-ligand for the activating receptor, they are tolerant toward the specific activating receptor. The activating receptor Ly49D recognizes $\mathrm{MHC}$ class I molecule $\mathrm{H}-2 \mathrm{D}^{\mathrm{d}}$. When NK cells develop in mice lacking $\mathrm{H}-2 \mathrm{D}^{\mathrm{d}}$, they are able to kill H-2Dd-expressing target cells. However, Ly49D ${ }^{+} \mathrm{NK}$ cells from $\mathrm{H}-2 \mathrm{D}^{\mathrm{d}}$-expressing mice show tolerance toward $\mathrm{H}-2 \mathrm{D}^{\mathrm{d}}$ expressing target cells (106). One possible mechanism for this self-tolerance is the coexpression of $\mathrm{H}-2 \mathrm{D}^{\mathrm{d}}$ recognizing inhibitory receptors Ly49A and Ly49G2 along with Ly49D on NK cells. The Rae-1 family of ligands that bind to the activating receptor NKG2D are known to be constitutively expressed in the embryos but absent in healthy adult tissues. Adoptive transfer of bone marrow cells from Rae-1$\varepsilon$ transgenic mice to syngeneic wild-type mice leads to efficient rejection of adoptively transferred NK cells (107). However, NK cells from Rae-1 $\varepsilon$ transgenic mice do not kill Rae-1-expressing tumor cells suggesting that NK cells developed in the presence of ligands for the specific activating receptor NKG2D show tolerogenic phenotype toward cells expressing those ligands (108).

The importance of inhibitory receptor-MHC class I engagement in NK cell tolerance and education can be understood from the fact that NK cells which develop in the absence of MHC class I molecules do not kill MHC class I-deficient tumor cell lines or reject $\mathrm{MHC}$ class I-deficient allogeneic bone marrow cells in vivo $(109,110)$. The types of inhibitory receptor expression on NK cells are varied and stochastic such that various populations of NK cell have a distinct combination of inhibitory receptors. Recent studies suggested that a significant number of NK cells in mouse and human either lack expression of any self-MHCspecific inhibitory receptors or express receptors specific for nonself-MHC class I. These subsets of NK cell are non-responsive to several activating receptor stimulations in vitro and fail to reject MHC class I-deficient bone marrow cells in vivo (111, 112). Thus, engagement of self-MHC class I with inhibitory receptor during NK cell development is necessary for full responsiveness of activating receptors and rejection of MHC-deficient cells and this process is known as NK cell education.

Several mechanisms have been proposed to explain NK cell education, one of the models being disarming model. According to this model, NK cells are by default responsive and become tolerant to normal cells after the acquisition of self-MHCspecific inhibitory receptor. The presence of activation pathways allows NK cells to reject target cells that lose MHC I molecules or upregulate ligands for activating receptors. However, if the NK cell fails to acquire self-MHC class I-specific inhibitory receptor, chronic stimulation by normal cells makes them hyporesponsive (113). In support of this model, it has been observed that transgenic C57BL/6 mice expressing $\mathrm{H}-2 \mathrm{D}^{\mathrm{d}}$ are able to reject $\mathrm{C} 57 \mathrm{BL} / 6$ bone marrow cells (express $\mathrm{H} 2-\mathrm{D}^{\mathrm{b}}$ ) while transgenic $\mathrm{H}-2 \mathrm{D}^{\mathrm{d}}$ mice having a mosaic expression of $\mathrm{H}-2 \mathrm{D}^{\mathrm{d}}$ and $\mathrm{H}-2 \mathrm{D}^{\mathrm{b}}$ are unable to reject $\mathrm{C} 57 \mathrm{BL} / 6$ bone marrow cells (114). The other model, known as licensing or arming model suggests that NK cells are initially hyporesponsive and become licensed or armed into effector cells after engagement of their inhibitory receptors with MHC class I during development. The fact that NK cell education does not require SHP-1 and SHIP-1 phosphatases suggests that inhibitory signals are indispensable for NK cell education and supports arming model (115). In addition to these, another model known as tuning or rheostat model is proposed where NK cell response is tuned by the number of self-MHC class I-specific receptor expressed on NK cell and the affinity of its cognate receptors. Thus, according to this model, NK cell education is a quantitative process, which depends on the strength of activating or inhibitory signal received by NK cell. If the strength of inhibitory signaling opposes chronic activating receptor stimuli, then NK cells are maintained in the highest responsive state. In contrast, strong stimulation without opposing inhibitory signal sends NK cells to lowest responsive state while intermediate net stimulation supports medium responsiveness (116). 


\section{NK Cell Memory and Antitumor Immunity}

Although NK cell is traditionally considered as a part of the innate immune system, now it has been shown that these cells also display memory cell-like features (117). NK cell memory response has been reported in three circumstances-antigenspecific memory NK cells in the liver, CMV-specific NK cells and cytokine-induced memory-like NK cells (118). Liver resident memory NK cells mediate hapten-specific contact hypersensitivity response and this reaction is abrogated in mice deficient for IL-12, IFN- $\gamma$, or IFN- $\alpha$ R signaling (119). Liver memory NK cell response to the melanocyte-specific prohapten monobenzone is dependent on macrophage activation through inflammasome NLRP3 and IL-18 (119). The memory NK cell response is also reported in MCMV virus infection. $\mathrm{Ly} 49 \mathrm{H}^{+} \mathrm{NK}$ cells recognize the $\mathrm{m} 157$ protein of MCMV virus and are capable of forming longlasting memory following MCMV reinfection (120). In human, memory NK cells respond to human CMV (HCMV) virus is known to express a high level of activating receptor NKG2C, and these $\mathrm{NKG}_{2} \mathrm{C}^{+} \mathrm{NK}$ cells expand during acute infection as well as during secondary challenge (121). Murine cytokine-induced memory NK cells initially activated with a high dose of IL-12 and IL-18 were shown to have increased cytokine secretion when restimulated after two weeks of primary antigen challenge (122). Similarly, human cytokine-induced memory NK cells with longterm effector response have been reported in response to IL-12, IL-15, and IL-18 stimulation (123).

Antitumor effect of memory NK cell has been studied mostly in $\mathrm{HCMV}$ model. CD56 ${ }^{\text {dim }} \mathrm{NKG} 2 \mathrm{C}^{+} \mathrm{NK}$ cells from a $\mathrm{HCMV}^{+}$ donor are shown to have increased TNF- $\alpha$ and IFN- $\gamma$ production in response to K562 tumor cell stimulation. These cells preferentially expand during HCMV reactivation in hematopoietic cell transplantation (HCT) recipients and play a significant role in mediating relapse protection with the better post-HCT outcome (124). Adoptively transferred IL-12-, IL-15- or IL-18-activated murine NK cells are shown to display memory features and inhibit tumor growth in IFN- $\gamma$ and perforin-dependent manner. These preactivated NK cells possess demethylation of $\mathrm{CpG}$ residue in the CNS1 region of IFN- $\gamma$ locus and show antitumor activity $(125,126)$. Human IL-12-, IL-15-, and IL-18-induced memory-like NK cells show higher expression of granzyme $\mathrm{B}$ and perforin and display enhanced cytotoxicity against K562 tumor cells (123). These NK cells are also shown to have increased TNF- $\alpha$ and IFN- $\gamma$ production in response to primary acute myeloid leukemia (AML) blasts and control AML growth in mice. Furthermore, its therapeutic use resulted in complete remission of nine AML patients in phase I clinical trial (127). Thus, harnessing the potential of NK cell memory for therapeutic purpose remains a promising translational approach to control tumor growth in the clinic.

\section{NK CELL-BASED CANCER IMMUNOTHERAPY}

\section{NK Cells in Cancer Immunosurveillance}

Natural killer cells play a pivotal role in cancer immunosurveillance and also cooperate with other adoptive immune cells for antitumor immunity $(98,128)$. Removal of NK cells has been shown to increase the incidence of MCA-induced sarcoma suggesting that NK cells are involved in tumor cell elimination (129). A study by O'Sullivan et al. provided further evidence for the role of $\mathrm{NK}$ cell in immunosurveillance where the incidence of MCA-induced sarcoma was greater in $\mathrm{RAG}^{-/-} \gamma \mathrm{c}^{-/-}$mice (lacking both adaptive immunity and NK cells) when compared with $\mathrm{RAG}^{-/-}$mice (lacking only adaptive immunity) (130). The mechanisms of NK cell elimination of MCA-induced sarcomas involve molecules like NKG2D, IFN- $\gamma$, and perforin $(97,131)$. The perforin-dependent NK cell activity was reported to control B cell lymphomas and mammary carcinoma (132). In a mouse model of liver carcinoma, it was observed that restoration of endogenous p53 in tumor cells promote NK cell-mediated elimination of senescent tumor cells (133). However, many tumors escape NK cell attack and grow progressively. Tumor cells secrete immunosuppressive factors such as TGF- $\beta$, VEGF, indoleamine 2,3-dioxygenase (IDO), prostaglandin E2 (PGE2), and adenosine which inhibit antitumor immune functions (134). Pietra et al. have demonstrated that melanoma cell-derived IDO and PGE2 inhibit the cytolytic activity of NK cells in vitro (135). We have also shown that melanoma tumor-infiltrating NK cells downregulate several activating receptors, upregulate inhibitory receptors and display poor degranulation when compared with NK cells in the secondary lymphoid tissues (98). The intratumoral NK cells are also known to have reduced proinflammatory cytokines and cytokine receptors expression which might hamper their antitumor response in the tumor microenvironment (98). Melanoma-associated fibroblasts have been reported to suppress the cytotoxic activity of NK cells in both contact-dependent and contact-independent manner (136). Several other suppressive cell types such as regulatory T cells (Tregs) and myeloid-derived suppressor cells (MDSCs) can impair antitumor immune response by inhibiting the function of tumor-specific effector T cells. Tregs, MDSC, and M2-macrophages also known to inhibit the cytolytic function of intratumoral NK cells through the production of IL-10 and TGF- $\beta$ (137-139).

\section{Adoptive NK Cell Therapy}

Harnessing NK cells for the therapeutic purpose is an attractive option and has received rejuvenating interest in recent times (Figure 5). NK cells immunotherapy offers several advantages. First, use of NK cells will bypass the need of antigen-specific T cells. Second, NK cells can directly kill tumor cells and can also rapidly secrete proinflammatory cytokines that can potentiate the adaptive immune response (128). Finally, NK cells are easy to isolate and manipulate and have a relatively short lifespan. Therefore, the possibility of overexpansion of transferred NK cells in the recipient's body is less.

The source of NK cells for adoptive therapy can be autologous (from the same patient) or allogeneic (from other healthy donors). In autologous NK cell-based adoptive therapy, NK cells are isolated from patients using CD56 beads, activated ex vivo and transfused back into the same patient followed by administration of cytokines such as IL-2 to support their in vivo expansion and stimulation (Figure 5A). Transfusion of ex vivo activated and expanded autologous NK cells in breast cancer, lymphoma, 


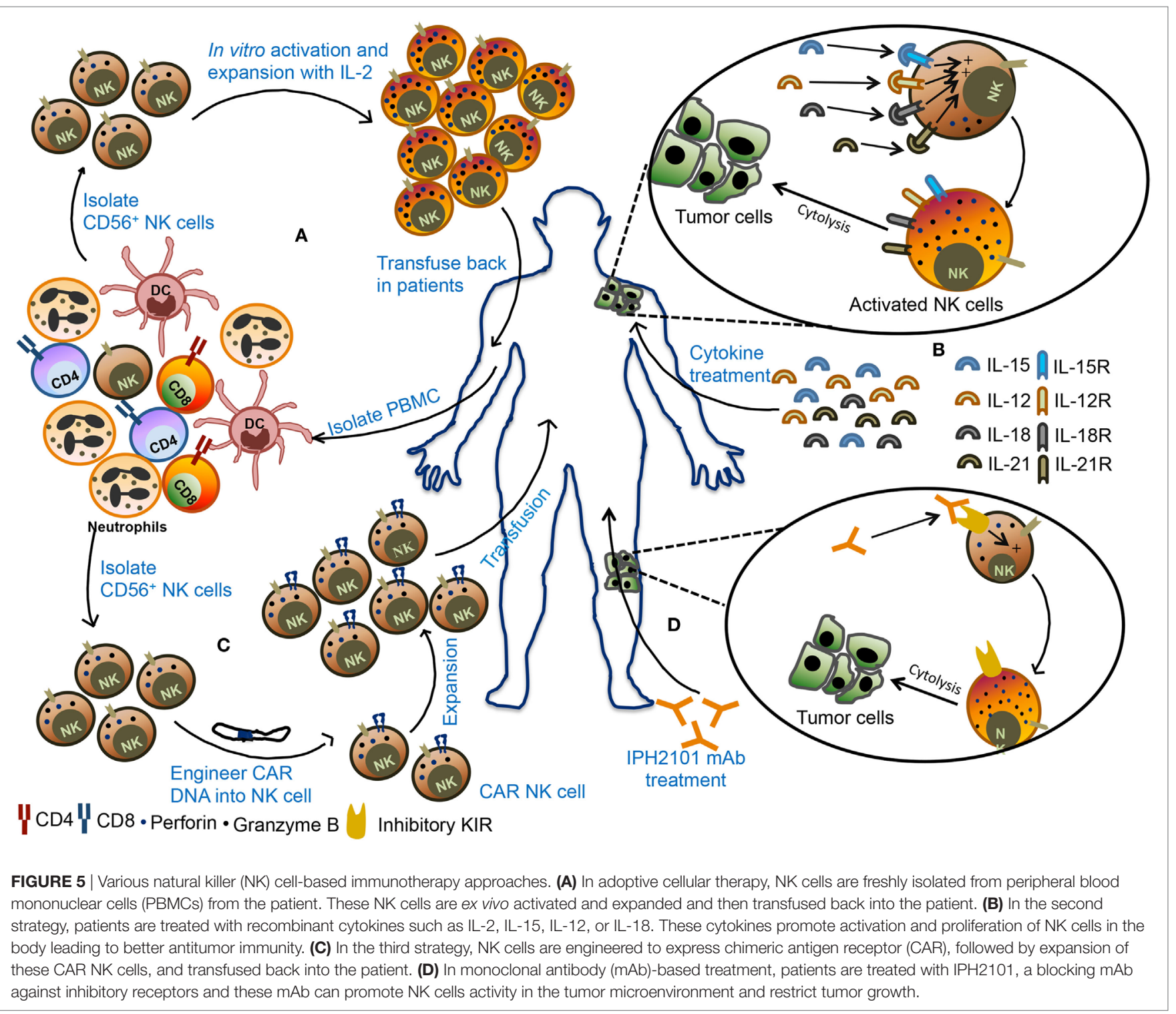

renal cell carcinoma, metastatic melanoma, and gastrointestinal cancer patients did not lead to favorable anticancer response (140-142). In most cases, there was either an increase in circulating NK cells or in vitro cytokine release or cytotoxicity by adoptively transferred NK cells but it was not enough to mediate tumor regression in the patients. The failure of autologous NK cell adoptive therapy to produce clinical outcome insisted on the use of allogeneic NK cells for immunotherapy. The advantage of allogeneic NK cells over autologous ones is due to its less likely to be inhibited by NK cell-mediated recognition of self-MHC molecules. Adoptive transfer of haploidentical NK cells from KIR-mismatched donor has been shown to be safe and also mediate complete remission in AML patients $(143,144)$. In most clinical trials of NK cell-based immunotherapy, peripheral blood (PB) was utilized as a source of NK cells. However, alternative sources of NK cells such as bone marrow, hESCs, and cord blood (CB) NK cells can also be explored for their therapeutic benefits as a cellular therapy for cancer. Successful expansion of CB NK cells using artificial antigen presenting cells has been reported and shown to have in vivo antitumor activity against multiple myeloma $(145,146)$. In contrast to hematological malignancies, NK cell-based immunotherapy was found to be less promising for solid tumor. Early phase clinical trial using the infusion of activated allogeneic NK cells in ovarian and breast cancer patients showed transient donor chimerism but did not show a significant expansion of transfused NK cells (147). NK cell-based immunotherapy of solid tumor posed several challenges such as reduced infiltration of NK cells into tumor microenvironment, lack of susceptibility of tumor cells to NK cell cytotoxicity and alteration of NK cell function by suppressive immune cells. Combining NK cell-based immunotherapy with approaches that can target immunosuppressed tumor microenvironment may provide benefit in the treatment of solid tumors. 


\section{Cytokine Therapy}

Several cytokines such as IL-2, IL-15, IL-12, IL-18, and IL-21 can activate and boost NK cell function (Figure 5B) (148-151). Among these, IL-15 stands out to be the most promising cytokine to be used as an activator of NK cells. Infusion of IL-15 into the metastatic malignant patients in a phase I clinical trial showed proliferation and expansion of NK cell along with other antitumor immune cells such as CD ${ }^{+} \mathrm{T}$ cells and $\gamma \delta \mathrm{T}$ cells. This study establishes a safe tolerance of IL-15 in patients and also achieved reduction of lung lesions in two patients (152). The superagonist IL-15-1L-15R $\alpha$-Sushi-Fc has been shown to promote NK cellmediated antitumor activity against breast, lung, and colon carcinomas in preclinical studies and holds a promising approach in the clinical trial $(153,154)$.

\section{Chimeric Antigen Receptor (CAR) NK Cell Therapy}

Adoptive transfer of NK cells that are engineered to express CAR against a specific tumor antigen such as ganglioside GD2, 2B4 (CD244) receptor, CD138, and CS1 have also been tested in several preclinical models (Figure 5C). In these models, CARtransduced NK cells demonstrated efficient killing of tumor cells in vivo and in vitro (155-158). Interestingly, NKG2D-DAP10$\mathrm{CD} 3 \zeta$-expressing NK cells are also shown to have enhanced cytotoxic activity and cytokine secretion potential in vitro and display enhanced antitumor activity to osteosarcoma (159). Large-scale isolation and expansion of NK cells from human PB and difficulties in the transfection of PB NK cells have hindered the production of human CAR NK cells. For these reasons, the human NK92 cell line consisting of activated NK cells have emerged as a popular choice for use in NK cell immunotherapy because of their relative ease in transfection. NK92 cells engineered to express CD19 CAR are shown to specifically target CD19 expressing leukemia cells $(160,161)$. Similarly, NK-92 cells transduced to express both wild-type and mutated EGFR CAR display cytolytic activity as well as IFN- $\gamma$ production against glioblastoma cells (162). NK-92 cells expressing receptor tyrosine kinase ErbB2 (HER2)-specific CAR were also shown to regress glioblastoma (GBM) tumors in an orthotopic GBM xenograft model (163). Currently, umbilical CB-derived CAR-engineered NK cells (CD19-CD28-zeta-2A-iCasp9-IL-15 transduced) are in clinical trial for relapsed/refractory CD19+ B lymphoid malignancies (NCT03056339). The NK-92 cell line engineered to express anti-CD33 or anti-CD7 linked to TCR zeta, CD28 and 4-1BB signaling domains are undergoing clinical trials for $\mathrm{CD} 33^{+} \mathrm{AML}$ (NCT02944162) or $\mathrm{CD}^{+}$relapsed or refractory leukemia and lymphoma (NCT02742727), respectively. These studies suggest that CAR NK cells have a strong potential to control the tumor growth that shows resistance to conventional immunotherapy.

\section{mAb-Based Therapy}

Natural killer cells express various activating, costimulatory, and inhibitory receptors that can be targeted to improve NK cell cytotoxicity (Table 1). One such receptor is CD16, which binds to Fc region of antibodies and promotes antibody-dependent cellmediated cytotoxicity (ADCC) of tumor cells. The combination of Rituximab and IL-2 has been shown to induce ADCC and increase NK cell activity (164). The ADCC activity of NK cells through CD16 can be enhanced by using bispecific or trispecific antibodies which incorporate Fv region recognizing tumor cell antigen along with $\mathrm{Fv}$ region that binds CD16. In the multiple myeloma patients, the effector immune cells do not easily recognize malignant plasma cells. To make these malignant cells as effective target to NK cell, a recombinant bispecific protein (ULBP2-BB4) were developed where ULBP2 interact with NKG2D on NK cells and BB4 moiety binds to CD138 expressed on the plasma cells. This bispecific fusion protein showed enhanced NK cell-mediated elimination of primary malignant plasma cells in the allogeneic and autologous setting and CD138 human multiple myeloma cell lines, U-266 and RPMI-8226 (165). Administration of IL-15R $\alpha$ chain in exosome along with NKG2D or NKp30 ligand to restore NK cell function has also been proved to be beneficial and resulted in progression-free survival in metastatic melanoma and non-small cell lung cancer patients (166). Further, blockade of inhibitory receptor signaling and immune checkpoints might serve as an alternative strategy to boost NK cell function (Figure 5D). Although tumor cells downregulate HLA class I, many tumor cells retain MHC class I molecules and their interaction with inhibitory receptors expressed on NK cells might dampen NK cell function. In such scenario, blockade of HLA-inhibitory receptor interaction might prove to be beneficial. IPH2101, a human IgG mAb which blocks signaling mediated by inhibitory receptor KIR2DL-1, -2, -3 showed enhanced NK cell activation and complete remission in AML patient in the phase I clinical trial but failed to show substantial clinical benefits in multiple myeloma patients in phase II trial $(167,168)$. Blocking of NKG2A-HLA-E interactions was also shown to increase NK cell cytotoxic activity (169). IPH2201, a blocking mAb to NKG2A is currently in clinical trial for solid tumors (NCT02671435 and NCT02643550). In future, the combinatorial approach targeting a different aspect of NK cell function might prove beneficial for the treatment of cancer.

\section{CONCLUSION}

The understanding of the cellular and molecular biology of NK cell has paved way for the design of NK cell-based immunotherapeutic strategies. However, the majority of the clinical trials attempting NK cell-based immunotherapy in solid tumor (including adoptive transfer of autologous, allogeneic NK cells, NK cell lines or CAR NK cells, cytokine-based therapy, anticancer inhibitors, or agonist of activating receptors) have only achieved low efficacy. One of the primary challenges for NK cell-based immunotherapy for solid tumor is migration and persistence of cytotoxic NK cells into the tumor microenvironment. The chemokines expressed in the tumor microenvironment and cognate expression of chemokine receptor on NK cells help in the efficient mobilization of NK cells in the tumor. CXCR3 has been shown to regulate the accumulation of CD27 $7^{\text {high }} \mathrm{NK}$ cells in subcutaneous lymphoma (170). The chemokines required for the migration of NK cells in various tumor tissues need to be identified. For the better efficacy of adoptive NK cell therapy in vitro activated, manipulated or genetically-modified NK cell has to 
have an expression of cognate chemokine receptors in order to efficiently mobilize into the tumor microenvironment. The use of an agonist of chemokine receptors that promote NK cell migration in the tumor microenvironment and combining cytokines or small molecule drugs that promote the cytolytic function and migration of $\mathrm{NK}$ cell in the tumor microenvironment should be explored as an alternative strategy. Besides, methodologies for the adequate large-scale manufacturing of large numbers of NK cells for its clinical use need to be developed.

Emerging evidence also suggests that tumor cells modulate the NK cell phenotype and function. To address this, in depth knowledge of the suppressive network that impairs NK cell effector function in the tumor microenvironment is needed. A comprehensive study of NK cell signaling pathways should also be carried out to identify novel targets that can be used to improve the NK cell antitumor response. Particular emphasis should be given on identification of unique pathways or checkpoints of

\section{REFERENCES}

1. Carrega P, Ferlazzo G. Natural killer cell distribution and trafficking in human tissues. Front Immunol (2012) 3:347. doi:10.3389/fimmu.2012.00347

2. King A, Balendran N, Wooding P, Carter NP, Loke YW. CD3-leukocytes present in the human uterus during early placentation: phenotypic and morphologic characterization of the CD56++ population. Dev Immunol (1991) 1(3):169-90. doi:10.1155/1991/83493

3. Bulmer JN, Williams PJ, Lash GE. Immune cells in the placental bed. Int J Dev Biol (2010) 54(2-3):281-94. doi:10.1387/ijdb.082763jb

4. Vacca P, Moretta L, Moretta A, Mingari MC. Origin, phenotype and function of human natural killer cells in pregnancy. Trends Immunol (2011) 32(11):517-23. doi:10.1016/j.it.2011.06.013

5. Kondo M, Weissman IL, Akashi K. Identification of clonogenic common lymphoid progenitors in mouse bone marrow. Cell (1997) 91(5):661-72. doi:10.1016/S0092-8674(00)80453-5

6. Rosmaraki EE, Douagi I, Roth C, Colucci F, Cumano A, Di Santo JP. Identification of committed NK cell progenitors in adult murine bone marrow. Eur J Immunol (2001) 31(6):1900-9. doi:10.1002/1521-4141(200106)31:6<1900:: AID-IMMU1900>3.0.CO;2-M

7. Sojka DK, Tian Z, Yokoyama WM. Tissue-resident natural killer cells and their potential diversity. Semin Immunol (2014) 26(2):127-31. doi:10.1016/j. smim.2014.01.010

8. Lanier LL, Phillips JH, Hackett J Jr, Tutt M, Kumar V. Natural killer cells: definition of a cell type rather than a function. J Immunol (1986) 137(9):2735-9.

9. van der Touw W, Burrell B, Lal G, Bromberg JS. NK cells are required for costimulatory blockade induced tolerance to vascularized allografts. Transplantation (2012) 94(6):575-84. doi:10.1097/TP.0b013e318264d3c4

10. Lanier LL. Up on the tightrope: natural killer cell activation and inhibition. Nat Immunol (2008) 9(5):495-502. doi:10.1038/ni1581

11. Veillette A, Latour S, Davidson D. Negative regulation of immunoreceptor signaling. Annu Rev Immunol (2002) 20:669-707. doi:10.1146/annurev. immunol.20.081501.130710

12. Stebbins CC, Watzl C, Billadeau DD, Leibson PJ, Burshtyn DN, Long EO. Vav1 dephosphorylation by the tyrosine phosphatase SHP-1 as a mechanism for inhibition of cellular cytotoxicity. Mol Cell Biol (2003) 23(17):6291-9. doi:10.1128/MCB.23.17.6291-6299.2003

13. Vivier E, Nunes JA, Vely F. Natural killer cell signaling pathways. Science (2004) 306(5701):1517-9. doi:10.1126/science.1103478

14. Wong S, Freeman JD, Kelleher C, Mager D, Takei F. Ly-49 multigene family. New members of a superfamily of type II membrane proteins with lectin-like domains. J Immunol (1991) 147(4):1417-23.

15. Dam J, Guan R, Natarajan K, Dimasi N, Chlewicki LK, Kranz DM, et al. Variable MHC class I engagement by Ly 49 natural killer cell receptors demonstrated by the crystal structure of Ly49C bound to H-2K(b). Nat Immunol (2003) 4(12):1213-22. doi:10.1038/ni1006
NK cell activation that can be exploited to develop small molecules that stimulate NK cell function in the tumor microenvironment. The patient receiving radiation therapy or chemotherapy as part of condition regimen before NK cell transfusion and its effect on NK cell function need to be critically evaluated. Thus, understanding the cellular and molecular biology of NK cells will allow us to identify novel molecules that could be used as immunotherapy.

\section{AUTHOR CONTRIBUTIONS}

SP and GL conceived the idea and wrote the manuscript.

\section{ACKNOWLEDGMENTS}

SP received Senior Research Fellowship (SRF) from Council of Scientific and Industrial Research (CSIR), Government of India. The work was supported by the NCCS intramural grant.

16. Canossi A, Aureli A, Del Beato T, Rossi P, Franceschilli L, De Sanctis F, et al. Role of KIR and CD16A genotypes in colorectal carcinoma genetic risk and clinical stage. J Transl Med (2016) 14(1):239. doi:10.1186/s12967-016-1001-y

17. Rajalingam R. Overview of the killer cell immunoglobulin-like receptor system. Methods Mol Biol (2012) 882:391-414. doi:10.1007/978-1-61779-842-9_23

18. Yokoyama WM, Kim S. Licensing of natural killer cells by self-major histocompatibility complex class I. Immunol Rev (2006) 214:143-54. doi:10.1111/j.1600-065X.2006.00458.x

19. Borrego F, Ulbrecht M, Weiss EH, Coligan JE, Brooks AG. Recognition of human histocompatibility leukocyte antigen (HLA)-E complexed with HLA class I signal sequence-derived peptides by CD94/NKG2 confers protection from natural killer cell-mediated lysis. J Exp Med (1998) 187(5):813-8. doi:10.1084/jem.187.5.813

20. Carretero M, Cantoni C, Bellon T, Bottino C, Biassoni R, Rodriguez A, et al. The CD94 and NKG2-A C-type lectins covalently assemble to form a natural killer cell inhibitory receptor for HLA class I molecules. Eur J Immunol (1997) 27(2):563-7. doi:10.1002/eji.1830270230

21. Braud VM, Allan DS, O'Callaghan CA, Soderstrom K, D’Andrea A, Ogg GS, et al. HLA-E binds to natural killer cell receptors CD94/NKG2A, B and C. Nature (1998) 391(6669):795-9. doi:10.1038/35869

22. Lee N, Llano M, Carretero M, Ishitani A, Navarro F, Lopez-Botet $M$, et al. HLA-E is a major ligand for the natural killer inhibitory receptor CD94/ NKG2A. Proc Natl Acad Sci U S A (1998) 95(9):5199-204. doi:10.1073/ pnas.95.9.5199

23. Vance RE, Kraft JR, Altman JD, Jensen PE, Raulet DH. Mouse CD94/NKG2A is a natural killer cell receptor for the nonclassical major histocompatibility complex (MHC) class I molecule Qa-1(b). J Exp Med (1998) 188(10):1841-8. doi:10.1084/jem.188.10.1841

24. Martinez-Lostao L, Anel A, Pardo J. How do cytotoxic lymphocytes kill cancer cells? Clin Cancer Res (2015) 21(22):5047-56. doi:10.1158/1078-0432. CCR-15-0685

25. Jamieson AM, Diefenbach A, McMahon CW, Xiong N, Carlyle JR, Raulet DH. The role of the NKG2D immunoreceptor in immune cell activation and natural killing. Immunity (2002) 17(1):19-29. doi:10.1016/S10747613(02)00333-3

26. Garrity D, Call ME, Feng J, Wucherpfennig KW. The activating NKG2D receptor assembles in the membrane with two signaling dimers into a hexameric structure. Proc Natl Acad Sci U S A (2005) 102(21):7641-6. doi:10.1073/ pnas.0502439102

27. Gilfillan S, Ho EL, Cella M, Yokoyama WM, Colonna M. NKG2D recruits two distinct adapters to trigger NK cell activation and costimulation. Nat Immunol (2002) 3(12):1150-5. doi:10.1038/ni857

28. Upshaw JL, Arneson LN, Schoon RA, Dick CJ, Billadeau DD, Leibson PJ. NKG2D-mediated signaling requires a DAP10-bound Grb2-Vav1 intermediate and phosphatidylinositol-3-kinase in human natural killer cells. Nat Immunol (2006) 7(5):524-32. doi:10.1038/ni1325 
29. Billadeau DD, Upshaw JL, Schoon RA, Dick CJ, Leibson PJ. NKG2D-DAP10 triggers human NK cell-mediated killing via a Syk-independent regulatory pathway. Nat Immunol (2003) 4(6):557-64. doi:10.1038/ni929

30. Horng T, Bezbradica JS, Medzhitov R. NKG2D signaling is coupled to the interleukin 15 receptor signaling pathway. Nat Immunol (2007) 8(12):1345-52. doi:10.1038/ni1524

31. Sutherland CL, Chalupny NJ, Schooley K, VandenBos T, Kubin M, Cosman D. UL16-binding proteins, novel MHC class I-related proteins, bind to NKG2D and activate multiple signaling pathways in primary NK cells. J Immunol (2002) 168(2):671-9. doi:10.4049/jimmunol.168.2.671

32. Diefenbach A, Tomasello E, Lucas M, Jamieson AM, Hsia JK, Vivier E, et al. Selective associations with signaling proteins determine stimulatory versus costimulatory activity of NKG2D. Nat Immunol (2002) 3(12):1142-9. doi:10.1038/ni858

33. Kubin M, Cassiano L, Chalupny J, Chin W, Cosman D, Fanslow W, et al. ULBP1, 2, 3: novel MHC class I-related molecules that bind to human cytomegalovirus glycoprotein UL16, activate NK cells. Eur J Immunol (2001) 31(5):1428-37. doi:10.1002/1521-4141(200105)31:5<1428:AID-IMMU1428>3.0.CO;2-4

34. Zhang C, Zhang J, Niu J, Zhou Z, Zhang J, Tian Z. Interleukin-12 improves cytotoxicity of natural killer cells via upregulated expression of NKG2D. Hum Immunol (2008) 69(8):490-500. doi:10.1016/j.humimm.2008.06.004

35. Song H, Hur DY, Kim KE, Park H, Kim T, Kim CW, et al. IL-2/IL-18 prevent the down-modulation of NKG2D by TGF-beta in NK cells via the c-Jun N-terminal kinase (JNK) pathway. Cell Immunol (2006) 242(1):39-45. doi:10.1016/j.cellimm.2006.09.002

36. Zhang C, Zhang J, Sun R, Feng J, Wei H, Tian Z. Opposing effect of IFNgamma and IFNalpha on expression of NKG2 receptors: negative regulation of IFNgamma on NK cells. Int Immunopharmacol (2005) 5(6):1057-67. doi:10.1016/j.intimp.2005.02.003

37. Cerwenka A, Bakker AB, McClanahan T, Wagner J, Wu J, Phillips JH, et al. Retinoic acid early inducible genes define a ligand family for the activating NKG2D receptor in mice. Immunity (2000) 12(6):721-7. doi:10.1016/ S1074-7613(00)80222-8

38. Carayannopoulos LN, Naidenko OV, Fremont DH, Yokoyama WM. Cutting edge: murine UL16-binding protein-like transcript 1: a newly described transcript encoding a high-affinity ligand for murine NKG2D. J Immunol (2002) 169(8):4079-83. doi:10.4049/jimmunol.169.8.4079

39. Diefenbach A, Hsia JK, Hsiung MY, Raulet DH. A novel ligand for the NKG2D receptor activates NK cells and macrophages and induces tumor immunity. Eur J Immunol (2003) 33(2):381-91. doi:10.1002/immu.200310012

40. Cosman D, Mullberg J, Sutherland CL, Chin W, Armitage R, Fanslow W, et al. ULBPs, novel MHC class I-related molecules, bind to CMV glycoprotein UL16 and stimulate NK cytotoxicity through the NKG2D receptor. Immunity (2001) 14(2):123-33. doi:10.1016/S1074-7613(01)00095-4

41. Takada A, Yoshida S, Kajikawa M, Miyatake Y, Tomaru U, Sakai M, et al. Two novel NKG2D ligands of the mouse H60 family with differential expression patterns and binding affinities to NKG2D. J Immunol (2008) 180(3):1678-85. doi:10.4049/jimmunol.180.3.1678

42. Diefenbach A, Jamieson AM, Liu SD, Shastri N, Raulet DH. Ligands for the murine NKG2D receptor: expression by tumor cells and activation of NK cells and macrophages. Nat Immunol (2000) 1(2):119-26. doi:10.1038/77793

43. Smyth MJ, Swann J, Kelly JM, Cretney E, Yokoyama WM, Diefenbach A, et al. NKG2D recognition and perforin effector function mediate effective cytokine immunotherapy of cancer. J Exp Med (2004) 200(10):1325-35. doi:10.1084/jem.20041522

44. Groh V, Rhinehart R, Secrist H, Bauer S, Grabstein KH, Spies T. Broad tumor-associated expression and recognition by tumor-derived gamma delta T cells of MICA and MICB. Proc Natl Acad Sci U S A (1999) 96(12):6879-84. doi:10.1073/pnas.96.12.6879

45. Pende D, Rivera P, Marcenaro S, Chang CC, Biassoni R, Conte R, et al. Major histocompatibility complex class I-related chain A and UL16-binding protein expression on tumor cell lines of different histotypes: analysis of tumor susceptibility to NKG2D-dependent natural killer cell cytotoxicity. Cancer Res (2002) 62(21):6178-86.

46. Vetter CS, Groh V, thor Straten P, Spies T, Brocker EB, Becker JC. Expression of stress-induced MHC class I related chain molecules on human melanoma. J Invest Dermatol (2002) 118(4):600-5. doi:10.1046/j.1523-1747. 2002.01700.x
47. Friese MA, Platten M, Lutz SZ, Naumann U, Aulwurm S, Bischof F, et al. MICA/NKG2D-mediated immunogene therapy of experimental gliomas. Cancer Res (2003) 63(24):8996-9006.

48. Salih HR, Antropius H, Gieseke F, Lutz SZ, Kanz L, Rammensee HG, et al. Functional expression and release of ligands for the activating immunoreceptor NKG2D in leukemia. Blood (2003) 102(4):1389-96. doi:10.1182/ blood-2003-01-0019

49. Gasser S, Orsulic S, Brown EJ, Raulet DH. The DNA damage pathway regulates innate immune system ligands of the NKG2D receptor. Nature (2005) 436(7054):1186-90. doi:10.1038/nature03884

50. Eissmann P, Evans JH, Mehrabi M, Rose EL, Nedvetzki S, Davis DM. Multiple mechanisms downstream of TLR-4 stimulation allow expression of NKG2D ligands to facilitate macrophage/NK cell crosstalk. J Immunol (2010) 184(12):6901-9. doi:10.4049/jimmunol.0903985

51. Bui JD, Carayannopoulos LN, Lanier LL, Yokoyama WM, Schreiber RD. IFN-dependent down-regulation of the NKG2D ligand H60 on tumors. J Immunol (2006) 176(2):905-13. doi:10.4049/jimmunol.176.2.905

52. Vales-Gomez M, Chisholm SE, Cassady-Cain RL, Roda-Navarro P, Reyburn HT. Selective induction of expression of a ligand for the NKG2D receptor by proteasome inhibitors. Cancer Res (2008) 68(5):1546-54. doi:10.1158/00085472.CAN-07-2973

53. Skov S, Pedersen MT, Andresen L, Straten PT, Woetmann A, Odum N. Cancer cells become susceptible to natural killer cell killing after exposure to histone deacetylase inhibitors due to glycogen synthase kinase-3-dependent expression of MHC class I-related chain A and B. Cancer Res (2005) 65(23):11136-45. doi:10.1158/0008-5472.CAN-05-0599

54. Cantoni C, Biassoni R, Pende D, Sivori S, Accame L, Pareti L, et al. The activating form of CD94 receptor complex: CD94 covalently associates with the Kp39 protein that represents the product of the NKG2-C gene. Eur I Immunol (1998) 28(1):327-38. doi:10.1002/(SICI)1521-4141(199801)28:01<327:: AID-IMMU327>3.0.CO;2-O

55. Lanier LL, Corliss B, Wu J, Phillips JH. Association of DAP12 with activating CD94/NKG2C NK cell receptors. Immunity (1998) 8(6):693-701. doi:10.1016/ S1074-7613(00)80574-9

56. Vance RE, Jamieson AM, Raulet DH. Recognition of the class Ib molecule Qa-1(b) by putative activating receptors CD94/NKG2C and CD94/NKG2E on mouse natural killer cells. J Exp Med (1999) 190(12):1801-12. doi:10.1084/ jem.190.12.1801

57. Smith KM, Wu J, Bakker AB, Phillips JH, Lanier LL. Ly-49D and Ly-49H associate with mouse DAP12 and form activating receptors. J Immunol (1998) 161(1):7-10.

58. McVicar DW, Taylor LS, Gosselin P, Willette-Brown J, Mikhael AI, Geahlen RL, et al. DAP12-mediated signal transduction in natural killer cells. A dominant role for the Syk protein-tyrosine kinase. J Biol Chem (1998) 273(49):32934-42. doi:10.1074/jbc.273.49.32934

59. Smith HR, Heusel JW, Mehta IK, Kim S, Dorner BG, Naidenko OV, et al. Recognition of a virus-encoded ligand by a natural killer cell activation receptor. Proc Natl Acad Sci U S A (2002) 99(13):8826-31. doi:10.1073/ pnas.092258599

60. Silver ET, Gong D, Hazes B, Kane KP. Ly-49W, an activating receptor of nonobese diabetic mice with close homology to the inhibitory receptor Ly-49G, recognizes H-2D(k) and H-2D(d). J Immunol (2001) 166(4):2333-41. doi:10.4049/jimmunol.166.4.2333

61. Nakamura MC, Linnemeyer PA, Niemi EC, Mason LH, Ortaldo JR, Ryan JC, et al. Mouse Ly-49D recognizes H-2Dd and activates natural killer cell cytotoxicity. J Exp Med (1999) 189(3):493-500. doi:10.1084/jem.189.3.493

62. Silver ET, Gong DE, Chang CS, Amrani A, Santamaria P, Kane KP. Ly-49P activates NK-mediated lysis by recognizing H-2Dd. JImmunol (2000) 165(4):1771-81. doi:10.4049/jimmunol.165.4.1771

63. Abi-Rached L, Parham P. Natural selection drives recurrent formation of activating killer cell immunoglobulin-like receptor and Ly 49 from inhibitory homologues. J Exp Med (2005) 201(8):1319-32. doi:10.1084/jem.20042558

64. Sivori S, Vitale M, Morelli L, Sanseverino L, Augugliaro R, Bottino C, et al. p46, a novel natural killer cell-specific surface molecule that mediates cell activation. J Exp Med (1997) 186(7):1129-36. doi:10.1084/jem.186.7.1129

65. Vitale M, Bottino C, Sivori S, Sanseverino L, Castriconi R, Marcenaro E, et al. NKp44, a novel triggering surface molecule specifically expressed by activated natural killer cells, is involved in non-major histocompatibility 
complex-restricted tumor cell lysis. J Exp Med (1998) 187(12):2065-72. doi:10.1084/jem.187.12.2065

66. Pende D, Parolini S, Pessino A, Sivori S, Augugliaro R, Morelli L, et al. Identification and molecular characterization of NKp30, a novel triggering receptor involved in natural cytotoxicity mediated by human natural killer cells. J Exp Med (1999) 190(10):1505-16. doi:10.1084/jem.190.10.1505

67. Kruse PH, Matta J, Ugolini S, Vivier E. Natural cytotoxicity receptors and their ligands. Immunol Cell Biol (2014) 92(3):221-9. doi:10.1038/icb.2013.98

68. Lee KM, McNerney ME, Stepp SE, Mathew PA, Schatzle JD, Bennett M, et al. 2B4 acts as a non-major histocompatibility complex binding inhibitory receptor on mouse natural killer cells. J Exp Med (2004) 199(9):1245-54. doi:10.1084/jem.20031989

69. Vaidya SV, Stepp SE, McNerney ME, Lee JK, Bennett M, Lee KM, et al. Targeted disruption of the 2B4 gene in mice reveals an in vivo role of 2B4 (CD244) in the rejection of B16 melanoma cells. J Immunol (2005) 174(2):800-7. doi:10.4049/jimmunol.174.2.800

70. Tangye SG, Lazetic S, Woollatt E, Sutherland GR, Lanier LL, Phillips JH. Cutting edge: human $2 \mathrm{~B} 4$, an activating NK cell receptor, recruits the protein tyrosine phosphatase SHP-2 and the adaptor signaling protein SAP. J Immunol (1999) 162(12):6981-5.

71. Tangye SG, Cherwinski H, Lanier LL, Phillips JH. 2B4-mediated activation of human natural killer cells. Mol Immunol (2000) 37(9):493-501. doi:10.1016/ S0161-5890(00)00076-6

72. Rah SY, Kwak JY, Chung YJ, Kim UH. ADP-ribose/TRPM2-mediated Ca2+ signaling is essential for cytolytic degranulation and antitumor activity of natural killer cells. Sci Rep (2015) 5:9482. doi:10.1038/srep09482

73. Mallone R, Funaro A, Zubiaur M, Baj G, Ausiello CM, Tacchetti C, et al. Signaling through CD38 induces NK cell activation. Int Immunol (2001) 13(4):397-409. doi:10.1093/intimm/13.4.397

74. Sague SL, Tato C, Pure E, Hunter CA. The regulation and activation of CD44 by natural killer (NK) cells and its role in the production of IFN-gamma. J Interferon Cytokine Res (2004) 24(5):301-9. doi:10.1089/107999004323065093

75. Tan PH, Santos EB, Rossbach HC, Sandmaier BM. Enhancement of natural killer activity by an antibody to CD44. J Immunol (1993) 150(3):812-20.

76. Bryceson YT, Ljunggren HG, Long EO. Minimal requirement for induction of natural cytotoxicity and intersection of activation signals by inhibitory receptors. Blood (2009) 114(13):2657-66. doi:10.1182/blood-2009-01-201632

77. Bryceson YT, March ME, Ljunggren HG, Long EO. Synergy among receptors on resting NK cells for the activation of natural cytotoxicity and cytokine secretion. Blood (2006) 107(1):159-66. doi:10.1182/blood-2005-04-1351

78. Carlyle JR, Martin A, Mehra A, Attisano L, Tsui FW, Zuniga-Pflucker JC. Mouse NKR-P1B, a novel NK1.1 antigen with inhibitory function. J Immunol (1999) 162(10):5917-23.

79. Arase N, Arase H, Park SY, Ohno H, Ra C, Saito T. Association with FcRgamma is essential for activation signal through NKR-P1 (CD161) in natural killer (NK) cells and NK1.1+ T cells. J Exp Med (1997) 186(12): 1957-63. doi:10.1084/jem.186.12.1957

80. Bottino C, Castriconi R, Pende D, Rivera P, Nanni M, Carnemolla B, et al. Identification of PVR (CD155) and Nectin-2 (CD112) as cell surface ligands for the human DNAM-1 (CD226) activating molecule. J Exp Med (2003) 198(4):557-67. doi:10.1084/jem.20030788

81. Reymond N, Imbert AM, Devilard E, Fabre S, Chabannon C, Xerri L, et al. DNAM-1 and PVR regulate monocyte migration through endothelial junctions. J Exp Med (2004) 199(10):1331-41. doi:10.1084/jem.20032206

82. Topham NJ, Hewitt EW. Natural killer cell cytotoxicity: how do they pull the trigger? Immunology (2009) 128(1):7-15. doi:10.1111/j.1365-2567.2009.03123.x

83. Alter G, Malenfant JM, Altfeld M. CD107a as a functional marker for the identification of natural killer cell activity. JImmunol Methods (2004) 294(1-2):15-22. doi:10.1016/j.jim.2004.08.008

84. Pardo J, Balkow S, Anel A, Simon MM. Granzymes are essential for natural killer cell-mediated and perf-facilitated tumor control. Eur J Immunol (2002) 32(10):2881-7. doi:10.1002/1521-4141(2002010)32:10<2881:AIDIMMU2881>3.0.CO;2-K

85. Street SE, Cretney E, Smyth MJ. Perforin and interferon-gamma activities independently control tumor initiation, growth, and metastasis. Blood (2001) 97(1):192-7. doi:10.1182/blood.V97.1.192

86. van den Broek MF, Kagi D, Zinkernagel RM, Hengartner H. Perforin dependence of natural killer cell-mediated tumor control in vivo. Eur J Immunol (1995) 25(12):3514-6. doi:10.1002/eji.1830251246
87. Sonar S, Lal G. Role of tumor necrosis factor superfamily (TNFSF) in neuroinflammation and autoimmunity. Front Immunol (2015) 6:384. doi:10.3389/fimmu.2015.00364

88. Thorburn A. Death receptor-induced cell killing. Cell Signal (2004) 16(2):139-44. doi:10.1016/j.cellsig.2003.08.007

89. Screpanti V, Wallin RP, Ljunggren HG, Grandien A. A central role for death receptor-mediated apoptosis in the rejection of tumors by NK cells. J Immunol (2001) 167(4):2068-73. doi:10.4049/jimmunol.167.4.2068

90. Takeda K, Smyth MJ, Cretney E, Hayakawa Y, Kayagaki N, Yagita H, et al. Critical role for tumor necrosis factor-related apoptosis-inducing ligand in immune surveillance against tumor development. JExp Med (2002) 195(2):161-9. doi:10.1084/jem.20011171

91. Hashimoto W, Osaki T, Okamura H, Robbins PD, Kurimoto M, Nagata S, et al. Differential antitumor effects of administration of recombinant IL-18 or recombinant IL-12 are mediated primarily by Fas-Fas ligand- and perforininduced tumor apoptosis, respectively. J Immunol (1999) 163(2):583-9.

92. Shoae-Hassani A, Hamidieh AA, Behfar M, Mohseni R, MortazaviTabatabaei SA, Asgharzadeh S. NK cell-derived exosomes from NK cells previously exposed to neuroblastoma cells augment the antitumor activity of cytokine-activated NK cells. J Immunother (2017) 40(7):265-76. doi:10.1097/ CJI.0000000000000179

93. Lugini L, Cecchetti S, Huber V, Luciani F, Macchia G, Spadaro F, et al. Immune surveillance properties of human NK cell-derived exosomes. J Immunol (2012) 189(6):2833-42. doi:10.4049/jimmunol.1101988

94. Bluman EM, Bartynski KJ, Avalos BR, Caligiuri MA. Human natural killer cells produce abundant macrophage inflammatory protein-1 alpha in response to monocyte-derived cytokines. J Clin Invest (1996) 97(12):2722-7. doi:10.1172/JCI118726

95. Roda JM, Parihar R, Magro C, Nuovo GJ, Tridandapani S, Carson WE III. Natural killer cells produce $\mathrm{T}$ cell-recruiting chemokines in response to antibody-coated tumor cells. Cancer Res (2006) 66(1):517-26. doi:10.1158/00085472.CAN-05-2429

96. Fauriat C, Long EO, Ljunggren HG, Bryceson YT. Regulation of human NK-cell cytokine and chemokine production by target cell recognition. Blood (2010) 115(11):2167-76. doi:10.1182/blood-2009-08-238469

97. Kaplan DH, Shankaran V, Dighe AS, Stockert E, Aguet M, Old LJ, et al. Demonstration of an interferon gamma-dependent tumor surveillance system in immunocompetent mice. Proc Natl Acad Sci U S A (1998) 95(13):7556-61. doi:10.1073/pnas.95.13.7556

98. Paul S, Kulkarni N, Shilpi, Lal G. Intratumoral natural killer cells show reduced effector and cytolytic properties and control the differentiation of effector Th1 cells. Oncoimmunology (2016) 5(12):e1235106. doi:10.1080/ 2162402X.2016.1235106

99. Chaix J, Tessmer MS, Hoebe K, Fuseri N, Ryffel B, Dalod M, et al. Cutting edge: priming of NK cells by IL-18. J Immunol (2008) 181(3):1627-31. doi:10.4049/jimmunol.181.3.1627

100. Ortaldo JR, Winkler-Pickett R, Wigginton J, Horner M, Bere EW, Mason AT, et al. Regulation of ITAM-positive receptors: role of IL-12 and IL-18. Blood (2006) 107(4):1468-75. doi:10.1182/blood-2005-04-1579

101. Bellone G, Aste-Amezaga M, Trinchieri G, Rodeck U. Regulation of NK cell functions by TGF-beta 1. J Immunol (1995) 155(3):1066-73.

102. Cai G, Kastelein RA, Hunter CA. IL-10 enhances NK cell proliferation, cytotoxicity and production of IFN-gamma when combined with IL-18. Eur J Immunol (1999) 29(9):2658-65. doi:10.1002/(SICI)1521-4141(199909) 29:09<2658::AID-IMMU2658>3.3.CO;2-7

103. Cho D, Kim TG, Lee W, Hwang YI, Cho HI, Han H, et al. Interleukin-18 and the costimulatory molecule B7-1 have a synergistic anti-tumor effect on murine melanoma; implication of combined immunotherapy for poorly immunogenic malignancy. J Invest Dermatol (2000) 114(5):928-34. doi:10.1038/sj.jid.5600685

104. Frederiksen KS, Lundsgaard D, Freeman JA, Hughes SD, Holm TL, Skrumsager BK, et al. IL-21 induces in vivo immune activation of NK cells and CD8(+) T cells in patients with metastatic melanoma and renal cell carcinoma. Cancer Immunol Immunother (2008) 57(10):1439-49. doi:10.1007/ s00262-008-0479-4

105. Takaki R, Hayakawa Y, Nelson A, Sivakumar PV, Hughes S, Smyth MJ, et al. IL-21 enhances tumor rejection through a NKG2D-dependent mechanism. J Immunol (2005) 175(4):2167-73. doi:10.4049/jimmunol. 175.4.2167 
106. George TC, Ortaldo JR, Lemieux S, Kumar V, Bennett M. Tolerance and alloreactivity of the Ly49D subset of murine NK cells. J Immunol (1999) 163(4):1859-67.

107. Ogasawara K, Benjamin J, Takaki R, Phillips JH, Lanier LL. Function of NKG2D in natural killer cell-mediated rejection of mouse bone marrow grafts. Nat Immunol (2005) 6(9):938-45. doi:10.1038/ni1236

108. Champsaur M, Lanier LL. Effect of NKG2D ligand expression on host immune responses. Immunol Rev (2010) 235(1):267-85. doi:10.1111/j.01052896.2010.00893.x

109. Bix M, Liao NS, Zijlstra M, Loring J, Jaenisch R, Raulet D. Rejection of class I MHC-deficient haemopoietic cells by irradiated MHC-matched mice. Nature (1991) 349(6307):329-31. doi:10.1038/349329a0

110. Liao NS, Bix M, Zijlstra M, Jaenisch R, Raulet D. MHC class I deficiency: susceptibility to natural killer (NK) cells and impaired NK activity. Science (1991) 253(5016):199-202. doi:10.1126/science.1853205

111. Fernandez NC, Treiner E, Vance RE, Jamieson AM, Lemieux S, Raulet DH. A subset of natural killer cells achieves self-tolerance without expressing inhibitory receptors specific for self-MHC molecules. Blood (2005) 105(11):4416-23. doi:10.1182/blood-2004-08-3156

112. Yawata M, Yawata N, Draghi M, Little AM, Partheniou F, Parham P. Roles for HLA and KIR polymorphisms in natural killer cell repertoire selection and modulation of effector function. J Exp Med (2006) 203(3):633-45. doi:10.1084/jem.20051884

113. Gasser S, Raulet DH. Activation and self-tolerance of natural killer cells. Immunol Rev (2006) 214:130-42. doi:10.1111/j.1600-065X.2006.00460.x

114. Johansson MH, Bieberich C, Jay G, Karre K, Hoglund P. Natural killer cell tolerance in mice with mosaic expression of major histocompatibility complex class I transgene. J Exp Med (1997) 186(3):353-64. doi:10.1084/ jem.186.3.353

115. Kim S, Poursine-Laurent J, Truscott SM, Lybarger L, Song YJ, Yang L, et al. Licensing of natural killer cells by host major histocompatibility complex class I molecules. Nature (2005) 436(7051):709-13. doi:10.1038/nature03847

116. Brodin P, Karre K, Hoglund P. NK cell education: not an on-off switch but a tunable rheostat. Trends Immunol (2009) 30(4):143-9. doi:10.1016/j. it.2009.01.006

117. Kovalenko EI, Streltsova MA, Kanevskiy LM, Erokhina SA, Telford WG. Identification of human memory-like NK cells. Curr Protoc Cytom (2017) 79:9.50.1-9.50.11. doi:10.1002/cpcy.13

118. Paust S, Gill HS, Wang BZ, Flynn MP, Moseman EA, Senman B, et al. Critical role for the chemokine receptor CXCR6 in NK cell-mediated antigenspecific memory of haptens and viruses. Nat Immunol (2010) 11(12):1127-35. doi:10.1038/ni.1953

119. Majewska-Szczepanik M, Paust S, von Andrian UH, Askenase PW, Szczepanik M. Natural killer cell-mediated contact sensitivity develops rapidly and depends on interferon-alpha, interferon-gamma and interleukin-12. Immunology (2013) 140(1):98-110. doi:10.1111/imm.12120

120. Dokun AO, Kim S, Smith HR, Kang HS, Chu DT, Yokoyama WM. Specific and nonspecific NK cell activation during virus infection. Nat Immunol (2001) 2(10):951-6. doi:10.1038/ni714

121. Foley B, Cooley S, Verneris MR, Pitt M, Curtsinger J, Luo X, et al. Cytomegalovirus reactivation after allogeneic transplantation promotes a lasting increase in educated NKG2C+ natural killer cells with potent function. Blood (2012) 119(11):2665-74. doi:10.1182/blood-2011-10-386995

122. Keppel MP, Yang L, Cooper MA. Murine NK cell intrinsic cytokine-induced memory-like responses are maintained following homeostatic proliferation. Immunol (2013) 190(9):4754-62. doi:10.4049/jimmunol.1201742

123. Romee R, Schneider SE, Leong JW, Chase JM, Keppel CR, Sullivan RP, et al. Cytokine activation induces human memory-like NK cells. Blood (2012) 120(24):4751-60. doi:10.1182/blood-2012-04-419283

124. Cichocki F, Cooley S, Davis Z, DeFor TE, Schlums H, Zhang B, et al. CD56dimCD57+NKG2C+ NK cell expansion is associated with reduced leukemia relapse after reduced intensity HCT. Leukemia (2016) 30(2):456-63. doi:10.1038/leu.2015.260

125. Ni J, Miller M, Stojanovic A, Garbi N, Cerwenka A. Sustained effector function of IL-12/15/18-preactivated NK cells against established tumors. J Exp Med (2012) 209(13):2351-65. doi:10.1084/jem.20120944

126. Ni J, Holsken O, Miller M, Hammer Q, Luetke-Eversloh M, Romagnani C, et al. Adoptively transferred natural killer cells maintain long-term antitumor activity by epigenetic imprinting and CD4+ T cell help. Oncoimmunology (2016) 5(9):e1219009. doi:10.1080/2162402X.2016.1219009

127. Romee R, Rosario M, Berrien-Elliott MM, Wagner JA, Jewell BA, Schappe T, et al. Cytokine-induced memory-like natural killer cells exhibit enhanced responses against myeloid leukemia. Sci Transl Med (2016) 8(357):357ra123. doi:10.1126/scitranslmed.aaf2341

128. Sconocchia G, Eppenberger S, Spagnoli GC, Tornillo L, Droeser R, Caratelli S, et al. NK cells and T cells cooperate during the clinical course of colorectal cancer. Oncoimmunology (2014) 3(8):e952197. doi:10.4161/2162 4011.2014.952197

129. Smyth MJ, Crowe NY, Godfrey DI. NK cells and NKT cells collaborate in host protection from methylcholanthrene-induced fibrosarcoma. Int Immunol (2001) 13(4):459-63. doi:10.1093/intimm/13.4.459

130. O’Sullivan T, Saddawi-Konefka R, Vermi W, Koebel CM, Arthur C, White JM, et al. Cancer immunoediting by the innate immune system in the absence of adaptive immunity. J Exp Med (2012) 209(10):1869-82. doi:10.1084/ jem. 20112738

131. Smyth MJ, Swann J, Cretney E, Zerafa N, Yokoyama WM, Hayakawa Y. NKG2D function protects the host from tumor initiation. J Exp Med (2005) 202(5):583-8. doi:10.1084/jem.20050994

132. Smyth MJ, Thia KY, Street SE, MacGregor D, Godfrey DI, Trapani JA. Perforin-mediated cytotoxicity is critical for surveillance of spontaneous lymphoma. J Exp Med (2000) 192(5):755-60. doi:10.1084/jem.192.5.755

133. Iannello A, Thompson TW, Ardolino M, Lowe SW, Raulet DH. p53dependent chemokine production by senescent tumor cells supports NKG2Ddependent tumor elimination by natural killer cells. J Exp Med (2013) 210(10):2057-69. doi:10.1084/jem.20130783

134. Baginska J, Viry E, Paggetti J, Medves S, Berchem G, Moussay E, et al. The critical role of the tumor microenvironment in shaping natural killer cellmediated anti-tumor immunity. Front Immunol (2013) 4:490. doi:10.3389/ fimmu.2013.00490

135. Pietra G, Manzini C, Rivara S, Vitale M, Cantoni C, Petretto A, et al. Melanoma cells inhibit natural killer cell function by modulating the expression of activating receptors and cytolytic activity. Cancer Res (2012) 72(6):1407-15. doi:10.1158/0008-5472.CAN-11-2544

136. Balsamo M, Scordamaglia F, Pietra G, Manzini C, Cantoni C, Boitano M, et al. Melanoma-associated fibroblasts modulate NK cell phenotype and antitumor cytotoxicity. Proc Natl Acad Sci U S A (2009) 106(49):20847-52. doi:10.1073/pnas.0906481106

137. Trzonkowski P, Szmit E, Mysliwska J, Dobyszuk A, Mysliwski A. CD4+CD25+ T regulatory cells inhibit cytotoxic activity of T CD8+ and NK lymphocytes in the direct cell-to-cell interaction. Clin Immunol (2004) 112(3):258-67. doi:10.1016/j.clim.2004.04.003

138. Li H, Han Y, Guo Q, Zhang M, Cao X. Cancer-expanded myeloidderived suppressor cells induce anergy of NK cells through membrane-bound TGF-beta 1. J Immunol (2009) 182(1):240-9. doi:10.4049/ jimmunol.182.1.240

139. Cekic C, Day YJ, Sag D, Linden J. Myeloid expression of adenosine A2A receptor suppresses $\mathrm{T}$ and NK cell responses in the solid tumor microenvironment. Cancer Res (2014) 74(24):7250-9. doi:10.1158/0008-5472. CAN-13-3583

140. Rosenberg SA, Lotze MT, Muul LM, Leitman S, Chang AE, Ettinghausen SE, et al. Observations on the systemic administration of autologous lymphokineactivated killer cells and recombinant interleukin-2 to patients with metastatic cancer. N Engl J Med (1985) 313(23):1485-92. doi:10.1056/ NEJM198512053132327

141. Parkhurst MR, Riley JP, Dudley ME, Rosenberg SA. Adoptive transfer of autologous natural killer cells leads to high levels of circulating natural killer cells but does not mediate tumor regression. Clin Cancer Res (2011) 17(19):6287-97. doi:10.1158/1078-0432.CCR-11-1347

142. Sakamoto N, Ishikawa T, Kokura S, Okayama T, Oka K, Ideno M, et al. Phase I clinical trial of autologous NK cell therapy using novel expansion method in patients with advanced digestive cancer. J Transl Med (2015) 13:277. doi:10.1186/s12967-015-0632-8

143. Miller JS, Soignier Y, Panoskaltsis-Mortari A, McNearney SA, Yun GH, Fautsch SK, et al. Successful adoptive transfer and in vivo expansion of human haploidentical NK cells in patients with cancer. Blood (2005) 105(8):3051-7. doi:10.1182/blood-2004-07-2974 
144. Curti A, Ruggeri L, D’Addio A, Bontadini A, Dan E, Motta MR, et al. Successful transfer of alloreactive haploidentical KIR ligand-mismatched natural killer cells after infusion in elderly high risk acute myeloid leukemia patients. Blood (2011) 118(12):3273-9. doi:10.1182/blood-2011-01-329508

145. Shah N, Martin-Antonio B, Yang H, Ku S, Lee DA, Cooper LJ, et al. Antigen presenting cell-mediated expansion of human umbilical cord blood yields log-scale expansion of natural killer cells with anti-myeloma activity. PLoS One (2013) 8(10):e76781. doi:10.1371/journal.pone.0076781

146. Veluchamy JP, Heeren AM, Spanholtz J, van Eendenburg JD, Heideman DA, Kenter GG, et al. High-efficiency lysis of cervical cancer by allogeneic NK cells derived from umbilical cord progenitors is independent of HLA status. Cancer Immunol Immunother (2017) 66(1):51-61. doi:10.1007/s00262016-1919-1

147. Geller MA, Cooley S, Judson PL, Ghebre R, Carson LF, Argenta PA, et al. A phase II study of allogeneic natural killer cell therapy to treat patients with recurrent ovarian and breast cancer. Cytotherapy (2011) 13(1):98-107. doi:10.3109/14653249.2010.515582

148. McMichael EL, Jaime-Ramirez AC, Guenterberg KD, Luedke E, Atwal LS, Campbell AR, et al. IL-21 enhances natural killer cell response to cetuximabcoated pancreatic tumor cells. Clin Cancer Res (2017) 23(2):489-502. doi:10.1158/1078-0432.CCR-16-0004

149. Tietje A, Yang X, Yu X, Wei Y. MICA/IL-12: a novel bifunctional protein for killer cell activation. Oncol Rep (2017) 37(3):1889-95. doi:10.3892/ or.2017.5375

150. Kim M, Kim TJ, Kim HM, Doh J, Lee KM. Multi-cellular natural killer (NK) cell clusters enhance NK cell activation through localizing IL-2 within the cluster. Sci Rep (2017) 7:40623. doi:10.1038/srep40623

151. Marcais A, Cherfils-Vicini J, Viant C, Degouve S, Viel S, Fenis A, et al. The metabolic checkpoint kinase mTOR is essential for IL-15 signaling during the development and activation of NK cells. Nat Immunol (2014) 15(8):749-57. doi:10.1038/ni.2936

152. Conlon KC, Lugli E, Welles HC, Rosenberg SA, Fojo AT, Morris JC, et al. Redistribution, hyperproliferation, activation of natural killer cells and CD8 $\mathrm{T}$ cells, and cytokine production during first-in-human clinical trial of recombinant human interleukin-15 in patients with cancer. J Clin Oncol (2015) 33(1):74-82. doi:10.1200/JCO.2014.57.3329

153. Kim PS, Kwilas AR, Xu W, Alter S, Jeng EK, Wong HC, et al. IL-15 superagonist/IL-15RalphaSushi-Fc fusion complex (IL-15SA/IL-15RalphaSu-Fc; ALT-803) markedly enhances specific subpopulations of NK and memory CD8+ T cells, and mediates potent anti-tumor activity against murine breast and colon carcinomas. Oncotarget (2016) 7(13):16130-45. doi:10.18632/ oncotarget.7470

154. Ochoa MC, Fioravanti J, Rodriguez I, Hervas-Stubbs S, Azpilikueta A, Mazzolini G, et al. Antitumor immunotherapeutic and toxic properties of an HDL-conjugated chimeric IL-15 fusion protein. Cancer Res (2013) 73(1):139-49. doi:10.1158/0008-5472.CAN-12-2660

155. Altvater B, Landmeier S, Pscherer S, Temme J, Schweer K, Kailayangiri S, et al. 2B4 (CD244) signaling by recombinant antigen-specific chimeric receptors costimulates natural killer cell activation to leukemia and neuroblastoma cells. Clin Cancer Res (2009) 15(15):4857-66. doi:10.1158/1078-0432. CCR-08-2810

156. Esser R, Muller T, Stefes D, Kloess S, Seidel D, Gillies SD, et al. NK cells engineered to express a GD2-specific antigen receptor display built-in ADCC-like activity against tumour cells of neuroectodermal origin. J Cell Mol Med (2012) 16(3):569-81. doi:10.1111/j.1582-4934.2011.01343.x

157. Jiang H, Zhang W, Shang P, Zhang H, Fu W, Ye F, et al. Transfection of chimeric anti-CD138 gene enhances natural killer cell activation and killing of multiple myeloma cells. Mol Oncol (2014) 8(2):297-310. doi:10.1016/j. molonc.2013.12.001

158. Chu J, Deng Y, Benson DM, He S, Hughes T, Zhang J, et al. CS1-specific chimeric antigen receptor (CAR)-engineered natural killer cells enhance in vitro and in vivo antitumor activity against human multiple myeloma. Leukemia (2014) 28(4):917-27. doi:10.1038/leu.2013.279

159. Chang YH, Connolly J, Shimasaki N, Mimura K, Kono K, Campana D. A chimeric receptor with NKG2D specificity enhances natural killer cell activation and killing of tumor cells. Cancer Res (2013) 73(6):1777-86. doi:10.1158/0008-5472.CAN-12-3558

160. Oelsner S, Friede ME, Zhang C, Wagner J, Badura S, Bader P, et al. Continuously expanding CAR NK-92 cells display selective cytotoxicity against B-cell leukemia and lymphoma. Cytotherapy (2017) 19(2):235-49. doi:10.1016/j.jcyt.2016.10.009

161. Romanski A, Uherek C, Bug G, Seifried E, Klingemann H, Wels WS, et al. CD19-CAR engineered NK-92 cells are sufficient to overcome NK cell resistance in B-cell malignancies. J Cell Mol Med (2016) 20(7):1287-94. doi: $10.1111 /$ jcmm. 12810

162. Han J, Chu J, Keung Chan W, Zhang J, Wang Y, Cohen JB, et al. CARengineered NK cells targeting wild-type EGFR and EGFRvIII enhance killing of glioblastoma and patient-derived glioblastoma stem cells. Sci Rep (2015) 5:11483. doi: $10.1038 /$ srep 11483

163. Zhang C, Burger MC, Jennewein L, Genssler S, Schonfeld K, Zeiner P, et al. ErbB2/HER2-specific NK cells for targeted therapy of glioblastoma. J Nat Cancer Inst (2016) 108(5):1-12. doi:10.1093/jnci/djv375

164. Gluck WL, Hurst D, Yuen A, Levine AM, Dayton MA, Gockerman JP, et al. Phase I studies of interleukin (IL)-2 and rituximab in B-cell non-Hodgkin's lymphoma: IL-2 mediated natural killer cell expansion correlations with clinical response. Clin Cancer Res (2004) 10(7):2253-64. doi:10.1158/10780432.CCR-1087-3

165. von Strandmann EP, Hansen HP, Reiners KS, Schnell R, Borchmann P, Merkert S, et al. A novel bispecific protein (ULBP2-BB4) targeting the NKG2D receptor on natural killer (NK) cells and CD138 activates NK cells and has potent antitumor activity against human multiple myeloma in vitro and in vivo. Blood (2006) 107(5):1955-62. doi:10.1182/blood-2005-05-2177

166. Viaud S, Terme M, Flament C, Taieb J, Andre F, Novault S, et al. Dendritic cell-derived exosomes promote natural killer cell activation and proliferation: a role for NKG2D ligands and IL-15Ralpha. PLoS One (2009) 4(3):e4942. doi:10.1371/journal.pone.0004942

167. Vey N, Bourhis JH, Boissel N, Bordessoule D, Prebet T, Charbonnier A, et al. A phase 1 trial of the anti-inhibitory KIR mAb IPH2101 for AML in complete remission. Blood (2012) 120(22):4317-23. doi:10.1182/blood-201206- 437558

168. Korde N, Carlsten M, Lee MJ, Minter A, Tan E, Kwok M, et al. A phase II trial of pan-KIR2D blockade with IPH2101 in smoldering multiple myeloma. Haematologica (2014) 99(6):e81-3. doi:10.3324/haematol.2013.103085

169. Nguyen S, Beziat V, Dhedin N, Kuentz M, Vernant JP, Debre P, et al. HLA-E upregulation on IFN-gamma-activated AML blasts impairs CD94/NKG2Adependent NK cytolysis after haplo-mismatched hematopoietic SCT. Bone Marrow Transplant (2009) 43(9):693-9. doi:10.1038/bmt.2008.380

170. Wendel M, Galani IE, Suri-Payer E, Cerwenka A. Natural killer cell accumulation in tumors is dependent on IFN-gamma and CXCR3 ligands. Cancer Res (2008) 68(20):8437-45. doi:10.1158/0008-5472.CAN-08-1440

Conflict of Interest Statement: The authors declare that the research was conducted in the absence of any commercial or financial relationships that could be construed as a potential conflict of interest.

Copyright (c) 2017 Paul and Lal. This is an open-access article distributed under the terms of the Creative Commons Attribution License (CC BY). The use, distribution or reproduction in other forums is permitted, provided the original author(s) or licensor are credited and that the original publication in this journal is cited, in accordance with accepted academic practice. No use, distribution or reproduction is permitted which does not comply with these terms. 